\title{
Discussion on the Unified Survey and Evaluation of Cultivated Land Quality at County Scale for China's 3rd National Land Survey: A Case Study of Wen County, Henan Province
}

\author{
Rui Zhao ${ }^{1} \mathbb{1}$, Kening $\mathrm{Wu}^{1,2, *}$, Xiaoliang $\mathrm{Li}^{1}{ }^{1}, \mathrm{Nan}_{\mathrm{Gao}}{ }^{3}$ and Mingming $\mathrm{Yu}^{4}$ \\ 1 School of Land Science and Technology, China University of Geosciences, Beijing 100083, China; \\ zhaorui19941220@163.com (R.Z.); x11351710167@163.com (X.L.) \\ 2 Key Laboratory of Land Consolidation, Ministry of Natural Resources, Beijing 100035, China \\ 3 Haidian Branch of Beijing Municipal Commission of Planning and Natural Resources, Beijing 100142, China; \\ gn952999502@163.com \\ 4 Zhongcheng Think Tank (Urbanization Research Institute), Beijing City University, Beijing 100083, China; \\ mingming7hao@bcu.edu.cn \\ * Correspondence: wukening@cugb.edu.cn; Tel.: +86-13811916703
}

check for updates

Citation: Zhao, R.; Wu, K.; Li, X.; Gao, N.; Yu, M. Discussion on the Unified Survey and Evaluation of Cultivated Land Quality at County Scale for China's 3rd National Land Survey: A Case Study of Wen County, Henan Province. Sustainability 2021, 13, 2513. https://doi.org/10.3390/ su13052513

Received: 6 February 2021

Accepted: 22 February 2021

Published: 26 February 2021

Publisher's Note: MDPI stays neutral with regard to jurisdictional claims in published maps and institutional affiliations.

Copyright: (C) 2021 by the authors Licensee MDPI, Basel, Switzerland. This article is an open access article distributed under the terms and conditions of the Creative Commons Attribution (CC BY) license (https:// creativecommons.org/licenses/by/ $4.0 /)$.

\begin{abstract}
Under the task requirements of China's 3rd national land survey on the grade determination of cultivated land, research on a reasonable and unified survey and evaluation system of cultivated land quality (CLQ) is of great importance. From the three dimensions of agricultural climate, production potential, and health status components of cultivated land, six factors are selected in this study to construct a set of simple, practicable, and operable county-level CLQ survey and evaluation system. These factors are climate conditions of cultivated land, soil characteristics, tillage conditions, the attributes of cultivated land type, environmental conditions, and biological activity. The developed survey and evaluation system meets the demands of national engineering for the inclusion and coordination of multiple departments based on the current evaluation system and evaluation methodology of all relevant land administrative departments. Wen County, Henan Province is used for field verification and evaluation. Results demonstrate that the average quality index of cultivated land in Wen County is 2196.33, ranging from 660.70 to 2802.96 with the largest area of the first-class and second-class land accounting for $20.98 \%$ and $52.61 \%$ of the county's cultivated land, respectively; the third-class and fourth-class land, $12.63 \%$ and $13.78 \%$. The obvious regional differentiation characteristics are presented along the boundary of Qingfengling with the quality of northern cultivated land higher than that in the south. The comparison with the results of the national utilization gradation in 2018 infers that they are in accordance with the distribution of CLQ, which bears a significant positive correlation trend with the measured grain output of the field. The constructed evaluation system serves as a rewarding attempt of a unified survey and evaluation of CLQ at the county scale to reflect the production capacity of local crops, realize the sharing of data platforms, save manpower and capital investment, improve the practical connection of supervision and management of cultivated land protection in different departments, and meet the requirements of current cultivated land protection and management.
\end{abstract}

Keywords: evaluation system; inclusive coordination; unification; land quality

\section{Introduction}

The United Nations predicts that the world's population will grow at a rate of $0.96 \%$ per year by 2030 and exceed 9 billion by 2050. Nonetheless, the global per capita area of cultivated land has dropped from $4000 \mathrm{~m}^{2}$ in the 1960 s to below $2500 \mathrm{~m}^{2}$. Some studies have indicated that the total area of available cultivated land in the world can only be expanded by $4.3 \%$ by 2050 [1]. The land degradation is estimated to have been $23.5 \%$ [2], and 123 billion $\mathrm{m}^{2}$ of agricultural land is unsuitable for farming [3], including cultivated 
land, woodland, grassland, farmland water utilization land, and breeding water surface. In addition, the growing population results in the increasing pressure on survival and development in many areas [4]. On account of the influence of the COVID-19 pandemic in 2020, several countries have begun to curb food exports, and food security has once again become a public concern. Given that sudden global public health incidents have largely impacted the food supply system, demand for food security has become imperative for China, the world's most populous country. The guarantee of food production has become part and parcel of the main battlefield of the national economy. Representing the essence of land resources and a carrier of grain production, cultivated land plays an irreplaceable role in grain production, and the quality of cultivated land directly affects the development of agricultural production and is a significant contributor to grain output [5]. The evaluation of cultivated land quality (CLQ) is an indispensable part of the sustainable management of land resources, and it also lays foundation for eliminating poverty alleviation and development, realizing rural revitalization, promoting food security, and improving nutrition.

In the No. 1 Central Document of the Communist Party of China in 2019, the stability of grain yield is considered as the top priority to consolidate the foundation of agriculture and guarantee the effective supply of important agricultural products. The foundation of the national food security strategy lies in the protection of cultivated land. To ensure national food security [6], the shift from prioritizing annual production to the path of sustainable development of "storing food in land" is obligatory. The 3rd national land survey (hereinafter referred to as "the 3rd survey") starts from 2017, which is a national project to investigate the utilization and contamination of land in the whole of China [7], obtain true and accurate land basic data. As a national condition and national strength survey concerning national food security, CLQ survey and evaluation serves as a fundamental work of natural resource management as it provides crucial clues for drawing a clear picture of CLQ and strengthening the protection and construction of the red line of CLQ. Specifically, the results of CLQ evaluation can be used in areas such as (i) land use planning and land consolidation planning, (ii) delineating farmland protection contexts, (iii) establishing the equilibrium between acquisition and compensation of the cultivated land, (iv) calculating the compensation fees for land expropriation, and (v) managing high-standard farmland construction and other land improvement projects [5].

Since the establishment of the Ministry of Natural Resources of the People's Republic of China, three national standards, such as the "Gradation Regulations for Agricultural Land Quality" (GB/T28407-2012), are released after the efforts of more than ten years to strengthen the basic work of CLQ management. Through comprehensive consideration of climate, topography, soil, farmland infrastructure, land use level, and other factors, the technical evaluation system for the gradation of CLQ is established to promote the construction of a working system of "regular comprehensive evaluation, annually updated evaluation, and annual assessment over monitoring" and gradually accomplish a technical and working system for the investigation, evaluation, and monitoring of the CLQ grade. Under the new situation, the 3rd national land survey would be fully launched in 2018. If the grade determination of the agricultural land had been applied as the primary task of survey and evaluation of CLQ grade and the overall plan of the 3rd survey, it would have neither conformed to the requirements of the Central Document No. 4, that is, "(15) strengthening the investigation, evaluation, and monitoring of CLQ—establish and improve the evaluation system of CLQ and cultivated land productivity and ameliorate the evaluation indicator system and evaluation method" nor satisfied the practical demands for the cultivated land dynamic balance and improvement of CLQ of high-standard basic farmland [8]. Moreover, with the socioeconomic development, people's different demands for CLQ and discrepancy in the responsibilities among various land management departments results in differences in the emphasis of investigation and evaluation of CLQ [9]. Most of them assess the nature, economy, society, ecological quality, and productivity levels of cultivated land from the perspective of climate, terrain, and people. Then, they 
set up a series of relatively complex national and provincial parameters and coefficients with complicated steps of evaluation. The relevant standards only focus on a certain aspect, resulting in fragmentation of the attention and management of CLQ, and there is a certain degree of duplication in the evaluation indicators and methods, resulting in the heavy workload of basic investigation and calculation and failure to integrate and share data between different departments (Table 1). Furthermore, the three main land resource management departments (Ministry of Natural Resources, Ministry of Agriculture and Rural Affairs, and Ministry of Ecology and Environment) hold different opinions about the content, indicator, and method and technique of CLQ. These differences have an impact on the level and efficiency of CLQ management and hinder the construction of the "trinity" protection and supervision system of CLQ, quantity, and ecology. Generally speaking, the understanding of the connotation of CLQ should be deepened and taken all into account at a national level to establish a sound, inclusive, complete, and scientific system for the unified national survey and evaluation method of CLQ. Doing so not only integrates the international system but also adapts to the management system to satisfy the requirements of the national project so as to provide a strong support for the protection and supervision of cultivated land in China.

Table 1. Characteristics and application scope of China's main cultivated land quality (CLQ) evaluation results.

\begin{tabular}{|c|c|c|c|}
\hline Land Management Departments & Technical Standard & Features & Application of Results \\
\hline \multirow{3}{*}{$\begin{array}{l}\text { Ministry of Natural Resources of } \\
\text { the People's Republic of China }\end{array}$} & $\begin{array}{l}\text { Regulation for gradation on } \\
\text { agriculture land quality } \\
\text { (GB/T 28407-2012) }\end{array}$ & \multirow{2}{*}{$\begin{array}{l}\text { Divide the quality of cultivated } \\
\text { land by estimating the } \\
\text { productivity of cultivated land }\end{array}$} & \multirow{2}{*}{$\begin{array}{l}\text { Serving the balance of arable land } \\
\text { occupation and compensation, } \\
\text { permanent basic farmland } \\
\text { delimitation, land use planning } \\
\text { and land improvement services }\end{array}$} \\
\hline & $\begin{array}{l}\text { Regulation for gradation on } \\
\text { agriculture land quality } \\
\text { (GB/T 28405-2012) }\end{array}$ & & \\
\hline & $\begin{array}{l}\text { Specification of land quality } \\
\text { geochemical assessment } \\
\text { (DZ/T 0295-2016) }\end{array}$ & $\begin{array}{l}\text { Based on the content of beneficial } \\
\text { and harmful elements in the soil, } \\
\text { evaluate the health of the } \\
\text { cultivated land on the } \\
\text { geochemical status of the } \\
\text { cultivated land }\end{array}$ & $\begin{array}{l}\text { Serving the production of } \\
\text { agricultural products }\end{array}$ \\
\hline \multirow{2}{*}{$\begin{array}{l}\text { Ministry of Agriculture } \\
\text { and Rural Affairs of } \\
\text { the People's Republic of China }\end{array}$} & $\begin{array}{l}\text { Cultivated Land Quality grade } \\
\text { (GB/T 33469-2016) }\end{array}$ & $\begin{array}{l}\text { Classification of CLQ by } \\
\text { evaluating cultivated land fertility } \\
\text { and soil environmental quality }\end{array}$ & \multirow{2}{*}{$\begin{array}{l}\text { Service and cultivated land soil } \\
\text { fertilization improvement and } \\
\text { governance restoration }\end{array}$} \\
\hline & $\begin{array}{l}\text { Rules for soil quality and assessment } \\
\text { (NYT 163) }\end{array}$ & $\begin{array}{l}\text { Classification of CLQ by } \\
\text { evaluating soil fertility }\end{array}$ & \\
\hline $\begin{array}{l}\text { Ministry of Ecology and } \\
\text { Environment of the People's } \\
\text { Republic of China }\end{array}$ & $\begin{array}{l}\text { Environmental quality } \\
\text { standards for soils } \\
\text { (GB 15618-2008) }\end{array}$ & $\begin{array}{l}\text { Diagnose soil pollution by } \\
\text { investigating the levels of eight } \\
\text { heavy metal elements and one } \\
\text { organic pollutant in the soil }\end{array}$ & $\begin{array}{l}\text { Support classified management } \\
\text { and safe use of agricultural land }\end{array}$ \\
\hline
\end{tabular}

In recent years, the investigation and evaluation of CLQ has paid more and more attention to the protection of the comprehensive quality of cultivated land production, ecology and health [10-12], mainly related to soil quality assessment [13-15], soil health assessment [16-19], multifunctional analysis of cultivated land [20,21], accounting of cultivated land productivity [22-24], land production potential evaluation [25,26], soil safety evaluation [27-30], evaluation of cultivated land healthy productivity [31,32], land ecological research [33,34], and land remediation and utilization [35-38]. It shows that the evaluation of CLQ is constantly advancing with the times (Figure 1), and new content is constantly added [39]. With the introduction of new technology, quantitative research on CLQ evaluation has made great progress. The relatively mature methods and models embody the agroecological zones (AEZ) Wageningen model [40,41], modified method [42], Nemerow comprehensive pollution index method [43], fuzzy comprehensive evaluation method [44,45], plot method [46], and triangle model [47]. At present, most studies adopt multifactor comprehensive evaluation method to evaluate cultivated land or cultivated soil quality by selecting indicators from soil conditions and natural environment factors, 
and put forward a series of specific measures to improve CLQ. However, the measurement and characterization of CLQ remains open to dispute, and the confusing employment of evaluation indicators and methods for CLQ investigation leads to unclear conclusion. In addition, most of the relevant studies have focused principally on the evaluation of cultivated soil health/quality at small and medium spatial scales under a specific land use pattern or agricultural tillage conditions. Research at the cross-spatial scale or from multifunctional dimensions is limited [48], causing difficulties in meeting the requirements of scientific evaluation and management of cultivated land resources at different levels and objectives.

Constantly enrich and strive to be comprehensive

\begin{tabular}{|c|c|c|c|c|c|c|}
\hline & The first phase & The second phase & The third phase & The fourth phase & The fifth phase & The sixth phase \\
\hline Contents & Land suitability evaluation & $\begin{array}{l}\text { Land productivity } \\
\text { evaluation }\end{array}$ & \begin{tabular}{|c|} 
Land suitability and \\
productivity evaluation
\end{tabular} & $\begin{array}{l}\text { Soil health } \\
\text { assessment }\end{array}$ & $\begin{array}{c}\text { Land sustainability } \\
\text { evaluation }\end{array}$ & $\begin{array}{c}\text { Comprehensive land } \\
\text { evaluation }\end{array}$ \\
\hline Problems & $\begin{array}{c}\text { Excessive pursuit of } \\
\text { agricultural productivity led } \\
\text { to a series of problems such } \\
\text { as soil erosion }\end{array}$ & $\begin{array}{c}\text { Urgent need to } \\
\text { quantitatively } \\
\text { measure land } \\
\text { production potential }\end{array}$ & $\begin{array}{c}\text { Land use planning } \\
\text { needs to be controlled at } \\
\text { the macro level, as well } \\
\text { as specific divisions at } \\
\text { the micro level }\end{array}$ & $\begin{array}{c}\text { Soil and } \\
\text { environmental } \\
\text { health issues } \\
\text { affect human } \\
\text { health }\end{array}$ & $\begin{array}{l}\text { Land desertification, soil } \\
\text { erosion and other issues are } \\
\text { becoming more and more } \\
\text { serious, and social needs } \\
\text { are developing rapidly }\end{array}$ & $\begin{array}{l}\text { In the } 21 \text { st century, we } \\
\text { are facing problems such } \\
\text { as soil erosion, ecological } \\
\text { environment } \\
\text { deterioration, and soil } \\
\text { heavy metal pollution }\end{array}$ \\
\hline Demands & $\begin{array}{l}\text { Under the premise of } \\
\text { ensuring the land suitability, } \\
\text { maximize the land } \\
\text { production capacity }\end{array}$ & $\begin{array}{c}\text { Calculate land } \\
\text { production potential } \\
\text { and study regional } \\
\text { land population } \\
\text { carrying capacity }\end{array}$ & $\begin{array}{l}\text { Need to combine the } \\
\text { macro-land suitability } \\
\text { evaluation with the } \\
\text { micro-site evaluation }\end{array}$ & $\begin{array}{c}\text { Control and } \\
\text { monitor soil } \\
\text { pollutants, repair } \\
\text { contaminated } \\
\text { soil } \\
\end{array}$ & $\begin{array}{c}\text { Land management and } \\
\text { sustainable development } \\
\text { needs }\end{array}$ & $\begin{array}{c}\text { Establish a unified data } \\
\text { platform to effectively } \\
\text { monitor soil degradation, } \\
\text { soil pollution and other } \\
\text { issues }\end{array}$ \\
\hline $\begin{array}{l}\text { Main } \\
\text { examples } \\
\text { from other } \\
\text { countries }\end{array}$ & $\begin{array}{l}\text { USA: "Evaluation of Land } \\
\text { Resources Productive } \\
\text { Potential" (1961) FAO: "Land } \\
\text { Evaluation Outline" (1976) }\end{array}$ & $\begin{array}{c}\text { FAO: "Agricultural } \\
\text { Ecological Zone Law" } \\
(1978)\end{array}$ & $\begin{array}{c}\text { USA: "Land Evaluation } \\
\text { and Site Analysis" } \\
\text { (1983) }\end{array}$ & $\begin{array}{c}\text { Canada: } \\
\text { "National } \\
\text { Contaminated } \\
\text { Site Remediation } \\
\text { Plan" (1989) }\end{array}$ & $\begin{array}{c}\text { FAO: "Sustainable Land } \\
\text { Use Management Program" } \\
\text { (1993) }\end{array}$ & $\begin{array}{l}\text { EU: "Soil Environment } \\
\text { Monitoring Project" (2007 } \\
\text { to present) }\end{array}$ \\
\hline
\end{tabular}

Figure 1. The change process and main examples of research related to the evaluation of CLQ in the world.

In the current investigation and evaluation of the CLQ grade in China, the construction of the cultivated land resource management system lays a solid foundation for scientific research and management. A county is taken as the project unit and field evaluation unit to bear municipal, provincial, and national fruits. However, subject to the scientific methods and protection concepts at that time, the general principle of "solving different problems at different scales" in land evaluation has been ignored, so the hierarchical scale of evaluation has not been reflected and the needs of management at different levels have not been met. Farmers, counties, cities, provinces, and countries comprise the decision-making levels of cultivated land resource management and utilization in China, and the focus, evaluation basic units, and evaluation system frameworks vary at different levels of CLQ evaluation indicators and so do the evaluation procedures and methods and application of evaluation results. Given that China's current agricultural land gradation and CLQ evaluation all take county as the basic unit for the implementation of national and provincial policies and plans, county serves as the optimal scale of the sustainable utilization and management of cultivated land resources. Therefore, the unified survey and evaluation system for CLQ at the county scale enables to provide decision support for governments at all levels to formulate farmland protection red lines and food security policies. In comprehensive consideration of previous research, this study summarizes the advantages of each department's evaluation system on the basis of the existing evaluation system and evaluation method of each management department. This study also establishes a set of inclusive and coordinated survey and evaluation method of CLQ at the county level, complies with the sharing of basic survey data, adds the content of the cultivated land type and cultivated land planting attributes of the 3rd survey, with Wen County, Henan Province, the main grain production area in China, as example for field verification and evaluation (Figure 2). Striving to establish an overall concept, grasp the dynamic changes of CLQ, earnestly perform the legal duties of cultivated land protection and land resource 
investigation, strengthen the basic work of CLQ management, and carry out permanent basic farmland protection, high-standard farmland construction, and cultivated land for county-level administrative regions The balance of accountancy and supplementation has a certain scientific guiding role. In the context of the 3rd survey, the specific objectives of the study are: (1): clarify the connotation, composition, characteristics, and influencing factors of CLQ; (2) make full use of existing basic data to build a county-scale CLQ evaluation system; and (3) establish a quantifiable CLQ evaluation model.

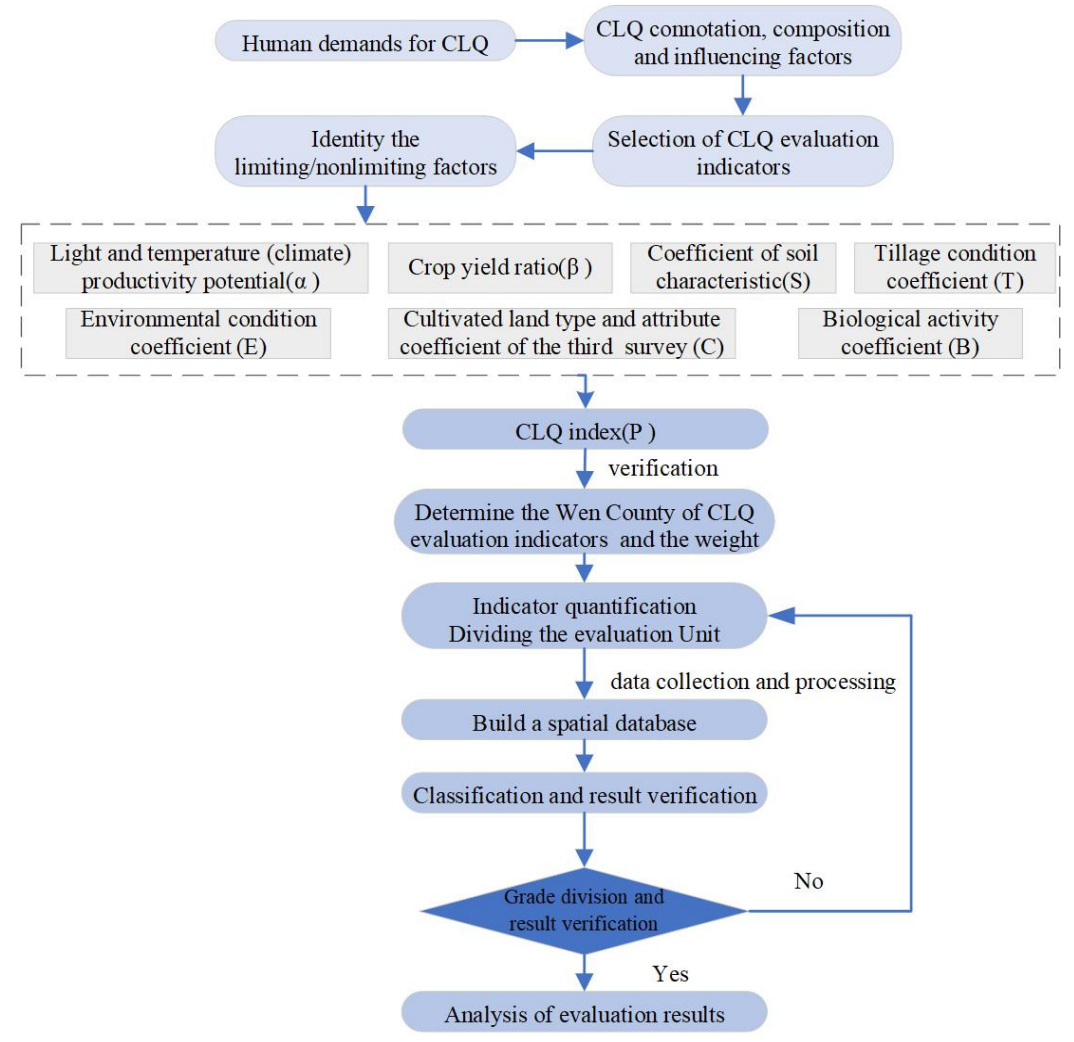

Figure 2. The research frame diagram.

\section{Materials and Methods}

\subsection{Cultivated Land System and Its Composing Elements}

Cultivated land is the basic resource and condition for human survival. The 3rd survey "Classification of Land Use Status" (GBT 21010-2017) states that cultivated land refers to land for growing crops, including mature land; newly developed, reclaimed, and reorganized land; and leisure land (including rotation land and fallow land). Cultivated land is mainly used for the cultivation of crops (including vegetables), with scattered fruit trees, mulberry trees, or other trees. It also indicates reclaimed shoaly land and tidal flat with the guarantee of harvesting one season on average every year. From the perspective of annotation, cultivated land includes the furrows, ditches, roads, and sills (ridges) with a width of less than $1.0 \mathrm{~m}$ in the south and less than $2.0 \mathrm{~m}$ in the north and the land for temporary cultivation of non-agricultural crops and other cultivated land temporarily converted to other uses. From the perspective of the formation process, cultivated land is a fertile loose surface layer formed by parent material under certain hydrothermal conditions and biological effects after being put into certain human labor. In terms of composing elements, cultivated land is a natural-social-economic complex composed of a variety of socioeconomic elements, including various natural factors such as climate, hydrology, geology, landform, soil, vegetation, and other inputs involving water, electricity, diesel, seeds, fertilizers, pesticides, plastic film, and crop output. As a regional system of the human-land relationship based on a certain area of the Earth, cultivated land is a dynamic 
structure composed of two subsystems of human society and geographical environment interlaced in a specific area $[49,50]$. Regarding the composition of the cultivated land system (Figure 3), this is the most closely related subsystem to the survival and development of human beings in the land use system. It is also a compound ecological system embedded in natural and social ecosystems with the highest human dependence [51,52]. In view of the above discussion, this study points out that cultivated land is the product of human activities and represents the land used for planting crops after human reclamation and maintaining periodic cultivation. As such, cultivated land is the most basic agricultural production material that cannot be replaced and the natural history complex formed by the combined effect of natural factors and social factors. Throughout, crop cultivation and food production attributes have always been the core.

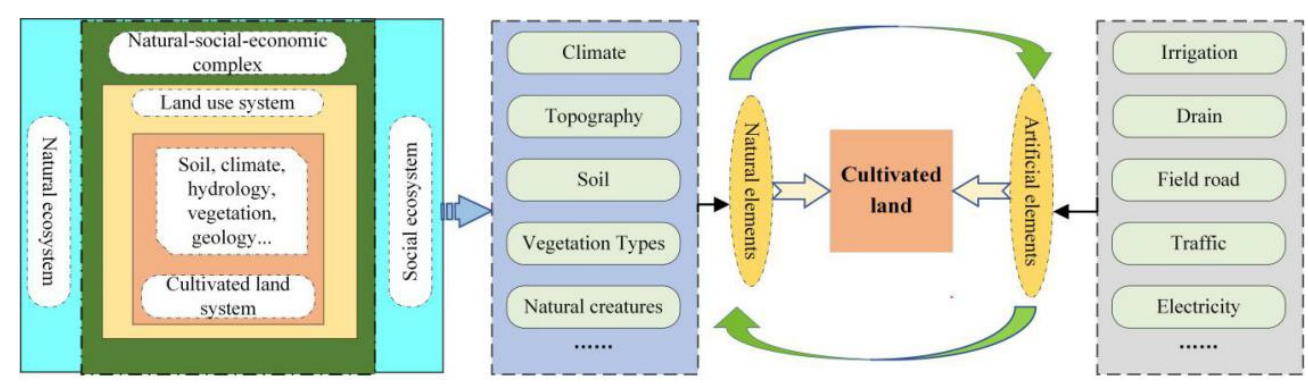

Figure 3. Cultivated land system and systematic elements.

As a necessary condition for the formation of cultivated soil, climate provides the essential energy for agricultural production, including heat, light, moisture, and air. Different climate types influence the types, distribution, cropping system, yield, and planting pattern of crops [53]. The different surface features of altitudes, slopes, slope lengths, and heights causes a variety of topographical landforms, such as mountains, hills, plains, plateaus, and basins, which affect the redistribution of materials and energy on the surface, and the types and spatial distribution pattern of cultivated land. The plains with low terrain and elevation bear superior soil development that is suitable for agricultural production and have high chance to be developed into high-quality cultivated land $[54,55]$. As the key composing element of cultivated land, soil enables to supply and regulate the water, nutrients, air, and heat required for crop growth, and soil with good texture, deep soil layer, rich organic matter, and barrier-free factors can offer long-term use for human beings [56,57]. Vegetation includes cultivated crops and naturally grown herbs, and agricultural protection forest, and the vegetation type suggests the cultivated land use type and suitability. It also illustrates the goals and methods of people's employment of cultivated land [58,59]. During agricultural production, the natural environment is utilized and transformed by humans. Infrastructure such as water conservancy, transportation, electricity, and rise of terrace and auxiliary facilities embodying seedling sheds, drying yards, and drying pools have been constructed for the rational and efficient use of cultivated land. Clearly, the input of social and economic resources serves as a fundamental element of human agricultural production and greatly influences the convenience and economy of agricultural production [60]. For example, to transform terrain and soil that are not conducive to the cultivation of crops to develop cultivated soil with high productivity, the construction of infrastructure involving irrigation, drainage facilities, field roads, forest nets, and others becomes the external guarantee for the optimal functioning and sustainable development of cultivated land.

\subsection{Theoretical Framework of CLQ Investigation and Evaluation}

With the development of the social economy, people's demand for cultivated land has changed from high yield at the very beginning to the comprehensive consideration of stable production, high efficiency, health, and sustainability [61]. Although China's current cultivated land use model can guarantee a certain level of food production in the short 
term, it reduces the sustainable food production capacity of cultivated land and threatens regional food security. Although the agricultural land gradation enables to illustrate the demand for cultivated land productivity at the macro level, the new circumstances set the high requirements beyond the reflection of the productivity level. The agricultural land gradation ought to meet the government's demand for the sustainable utilization and management of land [62] and the public's need for food security. Before the establishment of the Ministry of Natural Resources, the investigation and evaluation of CLQ was in the turbid situation of "nine dragons harnessing the rivers". The standards, indicators, and methods of the investigation and evaluation of CLQ differ among various departments. Although each department has its work basis, technical characteristics, and independent value, it may only concentrate on a certain level of demand for the management goal. As such, they cannot independently provide comprehensive and complete scientific data on the quality of cultivated land to meet the requirements of the "trinity" protection of cultivated land (i.e., quantity, quality, and ecology). At present, the technical systems for the investigation and evaluation of CLQ principally include "Gradation Regulations for Agricultural Land Quality" (GB/T 28407-2012) prepared by the Natural Resources Department to reflect the food production capacity, and "Land Quality Geochemical Evaluation Standards" (DZ/T 33469-2016), that is, a geochemical investigation system on the basis of the content of 54 elements in the topsoil; the compilation of "Cultivated Land Quality Gradation"(GB/T 33469-2016) led by the Ministry of Agriculture and Rural Affairs, which primarily aims to illustrate the basic fertility of cultivated land; "Soil Environmental Quality Agricultural Land Soil Pollution Risk Control Standards (Trial)" (GB/T 15618-2018) prepared by the Ministry of Ecology and Environment to investigate the content of eight heavy metal elements and one organic pollutant in the topsoil; these four types of investigation and evaluation systems lead to the unclear objectives of cultivated land's protection, supervision, and management. The evaluation of cultivated land productivity falls into the duty scope of the Ministry of Natural Resources and the Ministry of Agriculture and Rural Affairs. The nature of the agricultural land classification of the Ministry of Natural Resources is to highlight the natural endowment of the cultivated land (capacity) and measure the potential productivity of cultivated land determined by natural resource endowment from the climatic production potential (macro geographic zone) and the cultivated land production potential (regional soil, topography, irrigation, and drainage). From the perspective of agricultural production, the evaluation of CLQ gradation organized by the agricultural and rural sector assesses the capacity to keep continuous output and quality safety through the application of comprehensive index method to evaluate the cultivated land fertility, soil health status, and field infrastructure. The objectives of CLQ survey and evaluation of different departments have their own focuses, all of which support the protection and utilization of cultivated land resources, but differences are noted on the construction and management of CLQ.

Some studies have illustrated that the productivity of cultivated land is determined by climatic conditions, soil characteristics, and technical conditions. The factors affecting the quality of cultivated land embodies five aspects: geological characteristics, soil features, cultivation conditions, health status, and biological activity [63]. In this study, great efforts are made to integrate the related investigation and evaluation systems of CLQ among the management departments of the Ministry of Natural Resources and the Ministry of Agriculture and Rural Affairs to achieve the sharing of data on platforms. At the county level, "cultivated land quality" is defined as the food production capacity of cultivated land to support the construction of modern agricultural production and maintain its own safety and sustainable utilization. The formation of grain productivity of cultivated land depends on the four basic conditions of climate, soil, environment, and technology. According to the previous analysis, the theoretical framework of the unified investigation and evaluation of the CLQ at the county scale (Figure 4) is designed from three dimensions: the evaluation of climate productivity (agricultural climate component), fertility engineering status (production potential component), and ecological environment (physical condition 
component). With the existing agricultural land gradation system as the basis, the overall framework makes up for the deficiencies of the CLQ indicators in reflecting the basic fertility of the cultivated land, the state of the soil environment, and the construction of infrastructure. In the case of unrestricted terrain and soil conditions, the food productivity of cultivated land is primarily decided by climatic conditions. According to the agroecological location method, the maximum climatic production potential of different crops can be calculated under certain farming systems and labor inputs. On account of the limitation of soil and irrigation and drainage conditions, the climatic productivity of crops can be reduced. Consequently, the components of cultivated land production potential affected by soil characteristics, tillage conditions, the attributes of cultivated land type, and the physical condition components of cultivated land that are influenced by environmental conditions and biological activity are successively employed to revise the climatic production potential. The assessment of climatic production potential thus demonstrates mainly the light, temperature, precipitation, and crop growth period that have an impact on the grain yield. The evaluation of the cultivated land fertility engineering status illustrates principally the natural factors of soil fertility, landform conditions, and grain production potential determined by infrastructure involving water conservancy, transportation, and forest network. The assessment of the ecological environment of cultivated land reflects the conditions of sustainable use of cultivated land. Climate production potential continues to utilize the AEZ model to estimate the theoretical production capacity of each crop defined by the standard farming system at the county scale, represented by the light temperature/climate production potential index. The production potential of cultivated land is the compound consequence of various factors, including the soil characteristics, tillage conditions, and the attributes of the cultivated land type. The physical condition of cultivated land is jointly indicated by environmental conditions (safety) and biologically active (sustainability) factors. On this basis, the evaluation indicators are selected to match with quantifiable impact factors. These indicators adhere to the principles of measurable indicator data collection and indicator system integration with international standards, and they are linked with related basic work.

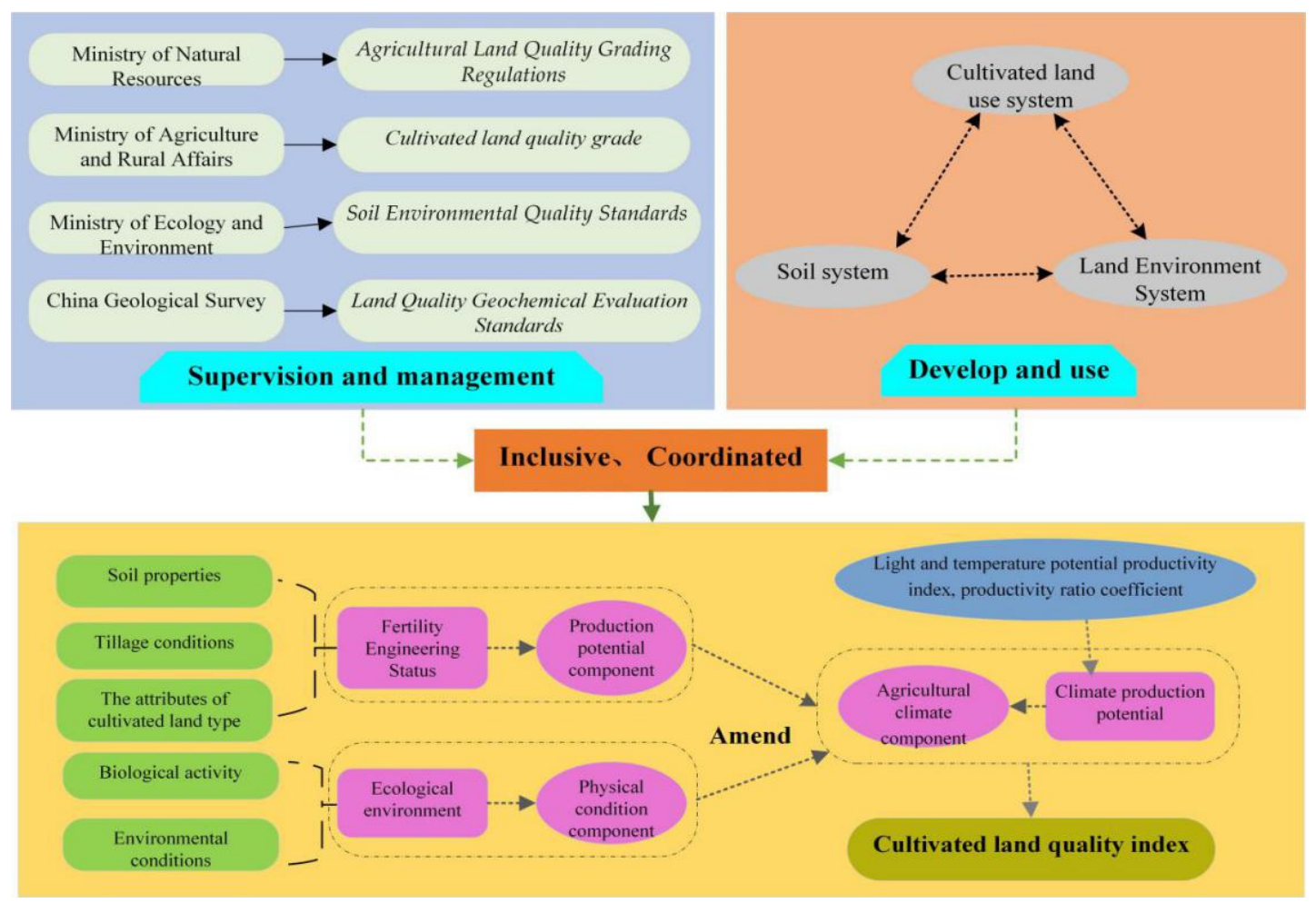

Figure 4. Theoretical framework for CLQ investigation and evaluation at the county level. 


\subsection{Construction of Investigation and Evaluation Indicator System of Cultivated Land}

On the strength of the above analysis, this study integrates and summarizes the relevant CLQ investigation and evaluation system of the "Grading Regulations on Agricultural Land Quality" (GB/T 28407-2012), "Cultivated Land Quality Gradation" (GB/T 334692016), and so on in the management departments of the Ministry of Natural Resources and the Ministry of Agriculture and Rural Affairs. In accordance with the principles of collaborative tolerance, absorption of existing research results, selection of indicators that can be measured scientifically, and avoidance of overlapping indicators, the evaluation indicator system of CLQ (Table 2) is established by virtue of the knowledge and production experience of related disciplines, such as soil science and cultivation, and consultation and integration of experts' advice. When agricultural production conditions are fully guaranteed, sufficient supply of water and $\mathrm{CO}_{2}$, and other suitable environmental conditions, climatic production potential is characterized by highest grain yield of ideal crop group with local light and heat resources, which demonstrates the difference of regional grain yield at the macro level. Designated crops are considered benchmark crops that represent the highest production capacity of cultivated land in an area with highest grain yield in theory. Doing so lays foundation for the realization of national comparability, and as a result, the light temperature/climate production potential index and yield ratio coefficient in the "Grading Regulations for Agricultural Land Quality" (GB/T 28407-2012) are used as the evaluation indicators of the climatic condition elements. The cultivated land fertility evaluation enables to showcase the background quality of cultivated land, so the 10 indicators in "Cultivated Land Quality Gradation" (GB/T 33469-2016) is adopted to represent soil properties in line with the regional characteristics, such as effective soil thickness, organic matter content, topographic location, arable layer texture, soil bulk density, texture configuration, soil nutrients, barrier layer depth from the surface, soil $\mathrm{pH}$, and arable layer thickness. Farmland infrastructure and the tillage condition of irrigation and drainage have an important influence on the quality of cultivated land, and the factors of tillage conditions are evaluated through the drainage conditions, irrigation conditions, and the degree of farmland afforestation in the "Cultivated Land Quality Gradation" (GB/T 334692016). Agriculture, rural areas, and peasants have always been the fundamental issues of China's construction and development. To realize agricultural modernization, it must continue to develop efficient agriculture. Essentially, it is necessary to improve the planting structure of cultivated land and rationally allocate cultivated land planting and utilization methods. In 2016, the eight ministries of the National Development and Reform Commission, the former Ministry of Land and Resources, jointly issued "the Plan for Restoration and Restoration of Cultivated Land, Grassland, Rivers, and Lakes (2016-2030)", which proposes that the rehabilitation of cultivated land should be adapted to local conditions. The plan also intends to adopt comprehensive measures of "maintenance", "retreat", "rest", "rotation", and "control." The protection of CLQ is closely related to the choice of protective farming systems [64], such as corn and legume intercropping and interplanting of trees and crops, which serve as crucial measures to cultivate fertility and improve grain yields [65]. Paddy fields, irrigated land, and dry land in the classification of current land use reflect the impact of differences in water conditions on farming methods and farmland quality [66]. To meet the requirements of "compensating paddy fields for paddy fields occupied" in the occupation-compensation balance and avoid "making up for occupied high quality land with the inferior land", the three-adjustable cultivated land types and the planting attributes of cultivated land are included in the evaluation system on the basis of the analysis of current literature and the 3rd survey data. Only healthy cultivated land guarantees the health of food given that heavy metals deposited in soil are easily migrated into groundwater to deteriorate water bodies and even transferred to humans through the food chain, which then has a negative influence on human health. Therefore, "Soil Environmental Quality Agricultural Land Soil Pollution Risk Control Standards (Trial)" (GB/T 15618-2018) is taken as reference for the elements of environmental conditions to select soil heavy metal pollution indicators. Although the increase or decrease of biological quantity does not di- 
rectly influence the quality of cultivated land, it has an indirect impact on the fertility level by changing the physical and chemical properties of the soil. On this basis, earthworms and microbial biomass carbon are selected to characterize biological activity $[67,68]$.

Table 2. CLQ investigation evaluation indicator system at the county level.

\begin{tabular}{|c|c|c|c|c|}
\hline CLQ Component & $\begin{array}{l}\text { Evaluation } \\
\text { Dimension }\end{array}$ & $\begin{array}{l}\text { Evaluation } \\
\text { Elements }\end{array}$ & Evaluation Indicator & Indicator Selection Source \\
\hline $\begin{array}{l}\text { Agricultural } \\
\text { climate } \\
\text { component }\end{array}$ & $\begin{array}{c}\text { Assessment of } \\
\text { climate production } \\
\text { potential }\end{array}$ & Climatic conditions & $\begin{array}{c}\text { Light and temperature potential } \\
\text { productivity index, } \\
\text { productivity ratio coefficient }\end{array}$ & $\begin{array}{l}\text { Regulation for gradation on } \\
\text { agriculture land quality } \\
\text { (GB/T 28407-2012) }\end{array}$ \\
\hline $\begin{array}{l}\text { Production } \\
\text { potential } \\
\text { component }\end{array}$ & \multirow{3}{*}{$\begin{array}{l}\text { Evaluation of } \\
\text { engineering status } \\
\text { of cultivated } \\
\text { land fertility }\end{array}$} & Soil properties & $\begin{array}{l}\text { Effective soil layer thickness, organic } \\
\text { matter content, terrain, soil texture of } \\
\text { plowed layer, soil bulk density, texture } \\
\text { configuration, soil nutrients, depth of } \\
\text { barrier layer from the surface, soil pH, } \\
\text { plowed layer thickness }\end{array}$ & $\begin{array}{l}\text { Cultivated land quality grade } \\
\text { (GB/T 33469-2016) }\end{array}$ \\
\hline \multirow{4}{*}{$\begin{array}{l}\text { Physical condition } \\
\text { component }\end{array}$} & & Tillage conditions & $\begin{array}{l}\text { Drainage conditions, irrigation } \\
\text { conditions, degree of } \\
\text { farmland afforestation }\end{array}$ & $\begin{array}{c}\text { Regulation for gradation } \\
\text { onagriculture land quality } \\
\text { (GB/T 28407-2012)/ Regulation for } \\
\text { gradation on agriculture land quality } \\
\text { (GB/T 28405-2012) }\end{array}$ \\
\hline & & $\begin{array}{c}\text { Attributes of } \\
\text { cultivated land type }\end{array}$ & $\begin{array}{l}\text { Cultivated land type, the planting } \\
\text { attributes of cultivated land }\end{array}$ & The third national land survey \\
\hline & \multirow{2}{*}{$\begin{array}{l}\text { Evaluation of } \\
\text { ecological } \\
\text { environment }\end{array}$} & $\begin{array}{l}\text { Environmental } \\
\text { conditions }\end{array}$ & Soil heavy metal pollution & $\begin{array}{l}\text { Environmental quality } \\
\text { standards for soils } \\
\text { (GB 15618-2008) }\end{array}$ \\
\hline & & Biological activity & $\begin{array}{l}\text { Soil earthworms, } \\
\text { soil microbial biomass carbon }\end{array}$ & $\begin{array}{l}\text { Guidelines for Soil Quality } \\
\text { Assessment in Conservation } \\
\text { Planning(USDA-NRCS) }\end{array}$ \\
\hline
\end{tabular}

\subsection{Investigation and Evaluation Method of CLQ}

The key to realizing the practical effect of the investigation and evaluation of CLQ lies in the construction of an investigation and evaluation system to form a comprehensive evaluation result. The comprehensive index method is widely used in the application of CLQ evaluation methods and the construction of evaluation models. According to relevant research $[5,69,70]$, CLQ is jointly affected by various factors. However, the simple summation of all factors is not suggested because some factors have critical restriction on the quality of cultivated land. By shedding light on the ideas of agricultural land quality gradation, the climatic production potential level bears relative stability free from casual transformation. In addition, the sustainable use of cultivated land soil type is dramatically influenced by soil type, cultivation conditions, the attributes of cultivated land type, biological activity, and environmental conditions. Therefore, on the foundation of the climatic production potential, the climatic production potential index is modified based on soil characteristics, tillage conditions, the attributes of cultivated land type, environmental conditions, and biological activity coefficients to obtain the CLQ index and divide the CLQ grade. The specific algorithm is shown as follows:

(1) Soil characteristic coefficient $S$, tillage condition coefficient $T$, cultivated land type of 3rd survey, and attribute coefficient $C$ :

$$
S / T / C=\sum_{\mathrm{i}=1}^{\mathrm{n}} M_{\mathrm{i}} N_{\mathrm{i}} / 100(\mathrm{i}=1,2,3 \ldots)
$$

where $S, T$, and $C$ indicate the coefficients of soil characteristics, tillage conditions, and cultivated land type attribute; $M_{i}$ means the corresponding score of the $i$-th secondary indicator of each element; $N_{i}$ refers to the weight of the $i$-th secondary indicator; and $\mathrm{n}$ is the number of indicators. 


\section{(2) Environmental condition coefficient $E$ :}

Within a certain concentration range, changes in the environmental conditions of cultivated land do not affect the crop yield but reduce the quality of the crop. Consequently, the environmental condition coefficient $(E)$ of cultivated land adopts the cumulative model of " $1+X$ ", that is, the unpolluted cultivated land is taken as the benchmark " 1 ".

(3) Biological activity coefficient $B$ :

The increase or decrease of biological quantity cannot directly affect the quality of cultivated land but exerts indirect influence on the soil fertility level by changing the physical and chemical properties of the soil. Additionally, accounting for the great influences of external factors on soil microorganisms and earthworms, the average values of soil microbial biomass carbon and soil earthworm quantity in regional survey samples are set as the benchmark " 1 ", and the cumulative model of " $1+X$ " is utilized to calculate the biological activity coefficient $(B)$ on the basis of grading standard.

(4) Quality index of cultivated land $P$ :

$$
P=\alpha \times \beta \times S \times T \times C \times E \times B
$$

where $\alpha$ indicates the light and temperature (climate) production potential index, and $\beta$ refers to the crop yield ratio coefficient.

\subsection{Overview of Research Area}

Located in the western part of the Yubei Plain, in Jiaozuo City, Henan Province, Wen County sees the Yellow River in the south and the Qin River in the north, adjoins Eastern Wuzhi county, and has Mengzhou in the west (Figure 5). With the latitude of $34^{\circ} 48^{\prime} 30^{\prime \prime} \mathrm{N}$ to $35^{\circ} 02^{\prime} 48^{\prime \prime} \mathrm{N}$ and longitude of $112^{\circ} 51^{\prime} 0^{\prime \prime} \mathrm{E}$ to $113^{\circ} 13^{\prime} 30^{\prime \prime} \mathrm{E}$, Wen County has 10 townships under its jurisdiction, covering $48,130.05$ ha of the administrative area. According to the 3rd survey database, the total area of cultivated land in Wen County is $32,917.17 \mathrm{ha}$, all of which is irrigated land, embodying 132.34 ha of grain and non-grain planting areas, 20.87 ha of uncultivated land, 49.86 ha of non-food crop planting area, and $32,714,100$ ha of common planting area. Wen County is located in the lower reaches of the Yellow River, with high terrain in the northwest and low in the southeast, forming a geomorphologic feature of middle hillock between the south beach and the depression in the north bounded by Qingfengling. To the south of Qingfengling is the floodplain of the Yellow River, accounting for $29.05 \%$ of the county's total area with the primary soil type of yellow-tide soil. To the north of Qingfengling is an alluvial fan-shaped plain, which accounts for $52.56 \%$ of the total area of the county. The soil type in the plain area is fluvo-aquic soil or brown fluvo-aquic soil, and the depression is filled with silt. With a mild climate throughout the year and four distinct seasons with an average annual temperature of approximately $14.4{ }^{\circ} \mathrm{C}$, Wen County bears the twice-yearly cropping system with the main crops of winter wheat and summer maize. The whole growth period of winter wheat is above $0{ }^{\circ} \mathrm{C}$ with the accumulated temperature of roughly $2000-2400{ }^{\circ} \mathrm{C}$. The required accumulated temperature of corn ranges from 2400 to $2600{ }^{\circ} \mathrm{C}$ with the annual average sunshine of $2389 \mathrm{~h}$ and annual precipitation of $541 \mathrm{~mm}$. Wen County has a long history of agriculture, sufficient labor resources, and a high level of agricultural intensification. As the first county north of the Yellow River with tons of grain, the wheat yield in Wen County has always maintained a leading position nationwide. As an important wheat seed production base in Henan Province, it is also an authentic production place for the "Four Major Huaiqing Medicines", namely, yam, rehmannia glutinosa, chrysanthemum, and achyranthes. All in all, conducting the investigation and evaluation of the CLQ in Wen County is of great significance. 


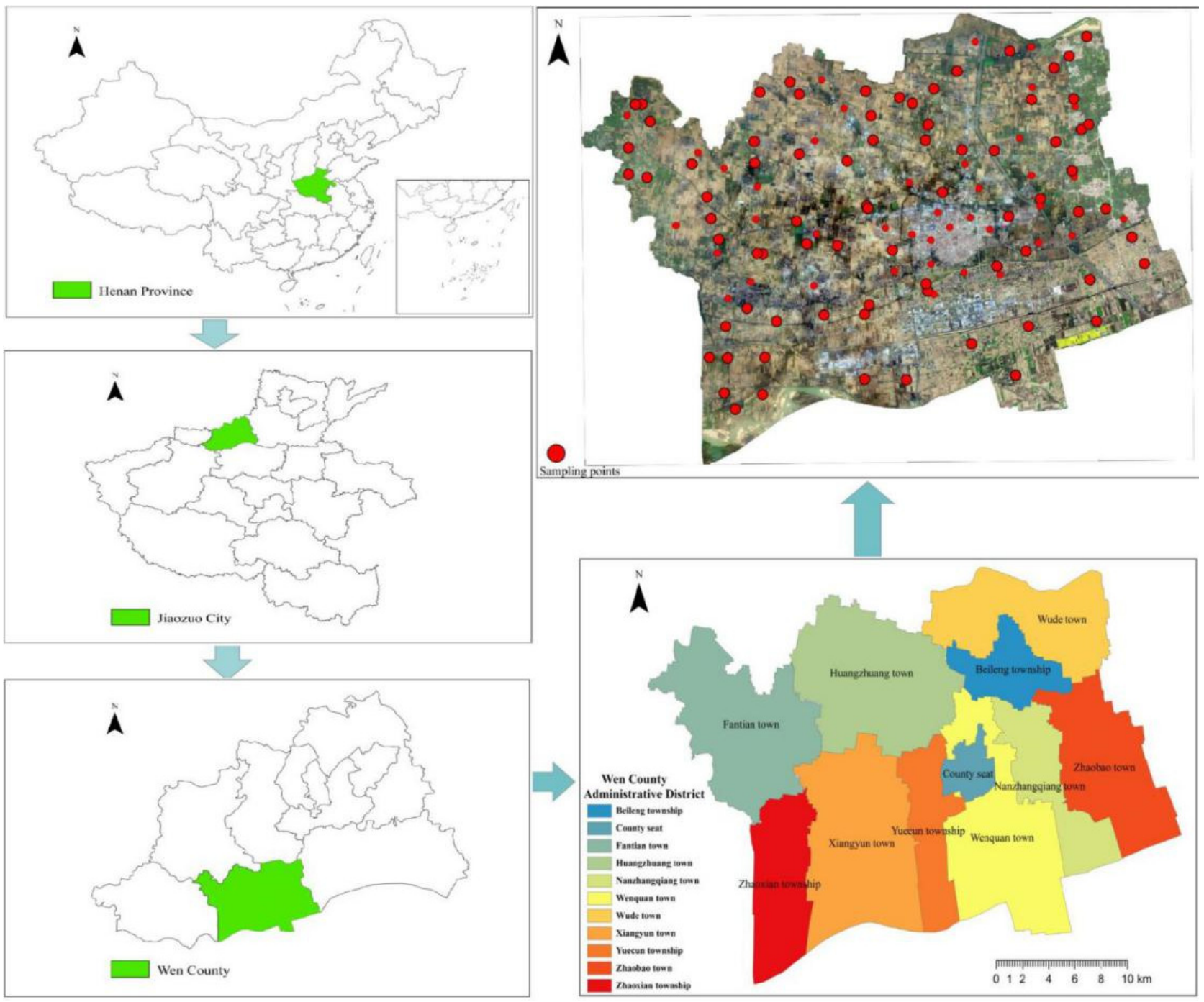

Figure 5. Location of the study area and distribution of sampling points. Source: Drawn by the authors.

\subsection{Data Acquisition and Processing}

In this research, data are obtained through a large amount of field soil sampling and laboratory testing in the early stage, with the specific data sources shown in Table 3. In particular, 5038 cultivated map patches in the cultivated map layer database of the 3rd survey in Wen County are taken as the research object in the thesis.

Table 3. Data sources and processing of CLQ investigation and evaluation indicators.

\begin{tabular}{|c|c|}
\hline Evaluation Indicator & Data Sources \\
\hline $\begin{array}{l}\text { Climate production } \\
\text { potential index }\end{array}$ & $\begin{array}{l}\text { The light and temperature productivity potential indexes of the winter wheat and summer maize are } \\
1221 \text { and } 2223 \text {, respectively in Wen through spatial interpolation }\end{array}$ \\
\hline Productive ratio factor & The wheat yield ratio coefficient in Wen is 1 , and the corn yield ratio coefficient is 0.808 \\
\hline Effective soil thickness & It is determined in the survey results of CLQ in Wen County in 2019 \\
\hline Organic content & $\begin{array}{l}\text { From September } 2017 \text { to October 2019, uniform sample layout and soil sampling were conducted to } \\
\text { gain138 soil samples (Figure 5), used the potassium dichromate method to measure data and each } \\
\text { evaluation unit is assigned through the interpolation of inverse distance weighting method }\end{array}$ \\
\hline
\end{tabular}


Table 3. Cont.

\begin{tabular}{|c|c|}
\hline Evaluation Indicator & Data Sources \\
\hline Terrain & $\begin{array}{l}\text { In line with the spatial distribution data of China's altitude (Chinese Academy of Sciences Resource and } \\
\text { Environmental Science Data Center with the data type of raster data and the accuracy of } 30 \mathrm{~m} \times 30 \mathrm{~m} \text { ) }\end{array}$ \\
\hline Plough layer texture & It is defined on the basis of the "surface soil texture" indicator in the survey results of CLQ in 2019 \\
\hline Soil bulk density & $\begin{array}{l}\text { From } 138 \text { soil samples, and the cutting-ring method was utilized to collect soil bulk density samples, } \\
\text { which are dried by the laboratory oven to calculate the data of soil bulk density, and each evaluation unit } \\
\text { is assigned through the interpolation of inverse distance weighting method }\end{array}$ \\
\hline Texture configuration & It is decided by the "profile configuration" indicator in the survey results of CLQ \\
\hline Soil nutrients & $\begin{array}{l}\text { With the application of the test results of } 2939 \text { samples of soil alkaline nitrogen, available phosphorus, } \\
\text { and available potassium in the soil fertilization station of Wen Agricultural Bureau in } 2016\end{array}$ \\
\hline $\begin{array}{l}\text { Depth of barrier layer } \\
\text { from the surface }\end{array}$ & $\begin{array}{c}\text { On the foundation of 1:50,000 soil map of Wen County, "Wen county soil", and 1:200,000 soil map of } \\
\text { Henan Province in the second national soil census }\end{array}$ \\
\hline Soil pH & $\begin{array}{c}\text { With the application of the test results of } 2939 \text { samples of soil pH in the soil fertilization station of Wen } \\
\text { Agricultural Bureau in } 2016\end{array}$ \\
\hline Plough thickness & The survey results of arable land quality in 2019 \\
\hline Drainage conditions & It is determined in the annual update results in 2018 \\
\hline Irrigation conditions & It is determined in the annual update results of CLQ in 2018 \\
\hline $\begin{array}{l}\text { The degree of farmland } \\
\text { afforestation }\end{array}$ & $\begin{array}{l}\text { Through high-resolution remote sensing images with an accuracy of } 1 \mathrm{~m} \text {, } \\
\text { the forest network along the roads and ditches in the field is interpreted and extracted. } \\
\text { Its density in the unit of the township is calculated }\end{array}$ \\
\hline Cultivated land type & The cultivated land layer database in the 3rd survey in 2019 \\
\hline $\begin{array}{l}\text { Planting attributes of } \\
\text { cultivated land }\end{array}$ & The cultivated land layer database in the 3rd survey in 2019 \\
\hline $\begin{array}{l}\text { Soil heavy metal } \\
\text { pollution }\end{array}$ & $\begin{array}{l}\text { There are } 2053 \text { samples data of the land quality geochemical evaluation database in 2016, and the soil } \\
\text { heavy metal element pollution index of the evaluation unit is equivalent to the maximum value of the } \\
\text { single factor pollution index of each heavy metal element }\end{array}$ \\
\hline Soil earthworm & $\begin{array}{l}\text { From } 86 \text { sample points were evenly distributed in towns and townships based on different soil types } \\
\text { with the elimination of ground cover and the excavation of the } 60 \mathrm{~cm} \times 60 \mathrm{~cm} \times 20 \mathrm{~cm} \text { quadrate by } \\
\text { shovel to count the number of earthworms in the soil block. }\end{array}$ \\
\hline $\begin{array}{l}\text { Soil microbial } \\
\text { biomass carbon }\end{array}$ & $\begin{array}{l}\text { From } 86 \text { soil samples were evenly divided into different townships on the basis of different soil types, } \\
\text { and the fresh soil samples were collected and refrigerated and stored at a constant temperature of } 4^{\circ} \mathrm{C} \\
\text { with the application of the thermal insulation box and dry ice to gain the soil microbial biomass carbon } \\
\text { data through the fumigation and other process of the fresh soil samples. Each evaluation unit is assigned } \\
\text { through the interpolation of ArcGIS inverse distance weighting method. }\end{array}$ \\
\hline
\end{tabular}

\subsection{Indicator Gradation and Weight Determination}

On account of the different nature of indicators and data sources, different methods of quantification and grading assignment are adopted. The indicators in the evaluation factors of soil characteristics, tillage conditions, and cultivated land type attributes are graded and assigned through Jenks Natural Breaks Classification on the basis of relevant research results such as "Grading Regulations for Agricultural Land Quality" (GB/T28407-2012) and "Cultivated Land Quality Gradation" (GB/T 33469-2016). As for the determination of indicator weights, three experts in this field were invited to apply expert choice in Analytic Hierarchy Process (AHP) software to make a pairwise comparison for deciding the relative importance of each level of indicators to the target of the previous level [24]. After inspecting the consistency of indicator weights at all levels of all experts, the average value was considered as the corresponding indicator weight. The index grading criteria and weights of the weighted summation method in the evaluation elements are demonstrated in Table 4. Table 5 illustrates the indicator grading rules of the " $1+X^{\prime \prime}$ accumulation model. 
Table 4. Grading assignment criteria and weights of indicators from the weighted summation method in the evaluation factor.

\begin{tabular}{|c|c|c|c|c|c|c|c|c|c|}
\hline \multirow[t]{2}{*}{ Evaluation Indicator } & \multicolumn{8}{|c|}{ Grading Assignment Criteria and Weights of Indicators } & \multirow{2}{*}{ Weight } \\
\hline & 100 & 90 & 80 & 70 & 60 & 50 & 40 & 30 & \\
\hline Terrain & \multicolumn{8}{|c|}{ Refer to "Cultivated Land Quality Gradation" (GB/T 33469-2016) } & 0.10 \\
\hline Effective soil thickness & $\geq 150 \mathrm{~cm}$ & $100-150 \mathrm{~cm}$ & & $60-100 \mathrm{~cm}$ & & $300-60 \mathrm{~cm}$ & & $<30 \mathrm{~cm}$ & 0.09 \\
\hline Organic content & $\geq 40 \mathrm{~g} / \mathrm{kg}$ & $400-30 \mathrm{~g} / \mathrm{kg}$ & $300-20 \mathrm{~g} / \mathrm{kg}$ & $200-10 \mathrm{~g} / \mathrm{kg}$ & $10-6 \mathrm{~g} / \mathrm{kg}$ & $<6 \mathrm{~g} / \mathrm{kg}$ & & & 0.15 \\
\hline Alkaline nitrogen & $>150 \mathrm{mg} \cdot \mathrm{kg}^{-1}$ & $>120-150 \mathrm{mg} \cdot \mathrm{kg}^{-1}$ & & $>90-120 \mathrm{mg} \cdot \mathrm{kg}^{-1}$ & & $>60-90 \mathrm{mg} \cdot \mathrm{kg}^{-1}$ & & $\leq 60 \mathrm{mg} \cdot \mathrm{kg}^{-1}$ & 0.13 \\
\hline Available phosphorus & $>40 \mathrm{mg} \cdot \mathrm{kg}^{-1}$ & $>20-40 \mathrm{mg} \cdot \mathrm{kg}^{-1}$ & & $>10-20 \mathrm{mg} \cdot \mathrm{kg}^{-1}$ & & $>5-10 \mathrm{mg} \cdot \mathrm{kg}^{-1}$ & & $\leq 5 \mathrm{mg} \cdot \mathrm{kg}^{-1}$ & \\
\hline Available potassium & $>200 \mathrm{mg} \cdot \mathrm{kg}^{-1}$ & $>150-200 \mathrm{mg} \cdot \mathrm{kg}^{-1}$ & & $>100-150 \mathrm{mg} \cdot \mathrm{kg}^{-1}$ & & $>50-100 \mathrm{mg} \cdot \mathrm{kg}^{-1}$ & & $\leq 50 \mathrm{mg} \cdot \mathrm{kg}^{-1}$ & \\
\hline Plough layer texture & Loam & Clay & & Sandy soil & & & Gravelly soil & & 0.13 \\
\hline Soil pH & $6.0-7.9$ & $5.5-6.0,7.9-8.5$ & $5.0-5.5,8.5-9.0$ & & $4.5-5.0$ & & & $<4.5,9.0-9.5$ & 0.07 \\
\hline Soil bulk density $\left(\mathrm{g} / \mathrm{cm}^{3}\right)$ & $1-1.25$ & $<1,1.25-1.35$ & & $1.35-1.45$ & & $1.45-1.55$ & & $>1.55$ & 0.05 \\
\hline Texture configuration & All loam & $\begin{array}{c}\text { Loam/sticky/sticky, } \\
\text { loam/sand, } \\
\text { sand/sticky/sticky }\end{array}$ & & Sand/sticky/sand & Loam/sand/sand & Sticky/sand/sand & All sand, all gravel & & 0.16 \\
\hline Plough layer thickness & $\geq 20 \mathrm{~cm}$ & $15-20 \mathrm{~cm}$ & & $10-15 \mathrm{~cm}$ & & & $<10 \mathrm{~cm}$ & & 0.11 \\
\hline Drainage conditions & No flood disaster & $\begin{array}{l}\text { water of field surface } \\
\text { for } 1-2 \text { days }\end{array}$ & & $\begin{array}{l}\text { water of field surface } \\
\text { for } 2-3 \text { days }\end{array}$ & & & $\begin{array}{l}\text { water of field surface } \\
\text { for more than } 3 \text { days }\end{array}$ & & 0.42 \\
\hline Degree of farmland afforestation & High & & Medium & & Low & & & & 0.19 \\
\hline Cultivated land type & Paddy field & Irrigable land & Dry land & & & & & & 050 \\
\hline Cultivated land planting attributes & Normal planting & Untilled & & $\begin{array}{c}\text { Grain and } \\
\text { non-grain rotation }\end{array}$ & & Grow non-food crops & & & 0.50 \\
\hline
\end{tabular}


Table 5. Grading assignment criteria and weights of indicators from the weighted summation method in the evaluation factor.

\begin{tabular}{|c|c|c|c|c|c|}
\hline Evaluation Dimension & Evaluation Factor & Evaluation Indicator & $\begin{array}{l}\text { Indicator } \\
\text { Grading }\end{array}$ & Score & Description \\
\hline \multirow{11}{*}{$\begin{array}{l}\text { Cultivated land } \\
\text { productivity potential }\end{array}$} & \multirow{6}{*}{ Biological activity } & \multirow{3}{*}{ Soil earthworm } & Level 1 & 0.20 & $>$ mean value of sampling points \\
\hline & & & Level 2 & 0.00 & mean value of sampling points \\
\hline & & & Level 3 & -0.20 & $<$ mean value of sampling points \\
\hline & & \multirow{3}{*}{$\begin{array}{l}\text { Soil microbial } \\
\text { biomass carbon }\end{array}$} & Level 1 & 0.20 & $>$ mean value of sampling points \\
\hline & & & Level 2 & 0.00 & mean value of sampling points \\
\hline & & & Level 3 & -0.20 & $<$ mean value of sampling points \\
\hline & \multirow{5}{*}{$\begin{array}{l}\text { Environmental } \\
\text { conditions }\end{array}$} & \multirow{5}{*}{ Soil heavy metals } & Level 1 & 0.00 & $p \leq 0.7$ \\
\hline & & & Level 2 & -0.10 & $0.7<p \leq 1.0$ \\
\hline & & & Level 3 & -0.20 & $1.0<p \leq 2.0$ \\
\hline & & & Level 4 & -0.30 & $2.0<p \leq 3.0$ \\
\hline & & & Level 5 & -0.40 & $p>3.0$ \\
\hline
\end{tabular}

\section{Results}

\subsection{Analysis of the Results of Investigation and Evaluation of CLQ}

According to the indicator system and weights determined above, the Wen County CLQ index (Figure 6) was investigated and evaluated by the ArcGIS 10.2 using the method and model of the CLQ survey evaluation method and model. The average index of CLQ in Wen County was 2196.33, ranging from 660.70 to 2802.96. In line with the ArcGIS, the cultivated land was divided into four grades through natural breakpoint method: first-class cultivated land [660.70, 1839.58]; second-class cultivated land [1839.58, 2107.93]; third-class cultivated land [2107.93, 2360.40); and fourth-class cultivated land [2360.40, 2802.96). The first-class and second-class land takes the predominate position of the quality of cultivated land in Wen County, of which the first-class land covers 6906.18 ha, accounting for $20.98 \%$ of the county's cultivated land. The largest amount of second-class was 17,316.95 ha, which was $52.61 \%$ of the county's cultivated land. The least amount of third-class land accounts for only $12.63 \%$ of the county's cultivated land with an area of 4156.82 ha. The fourth-class land had an area of 4573.23 ha, accounting for $13.78 \%$ of the county's cultivated land.

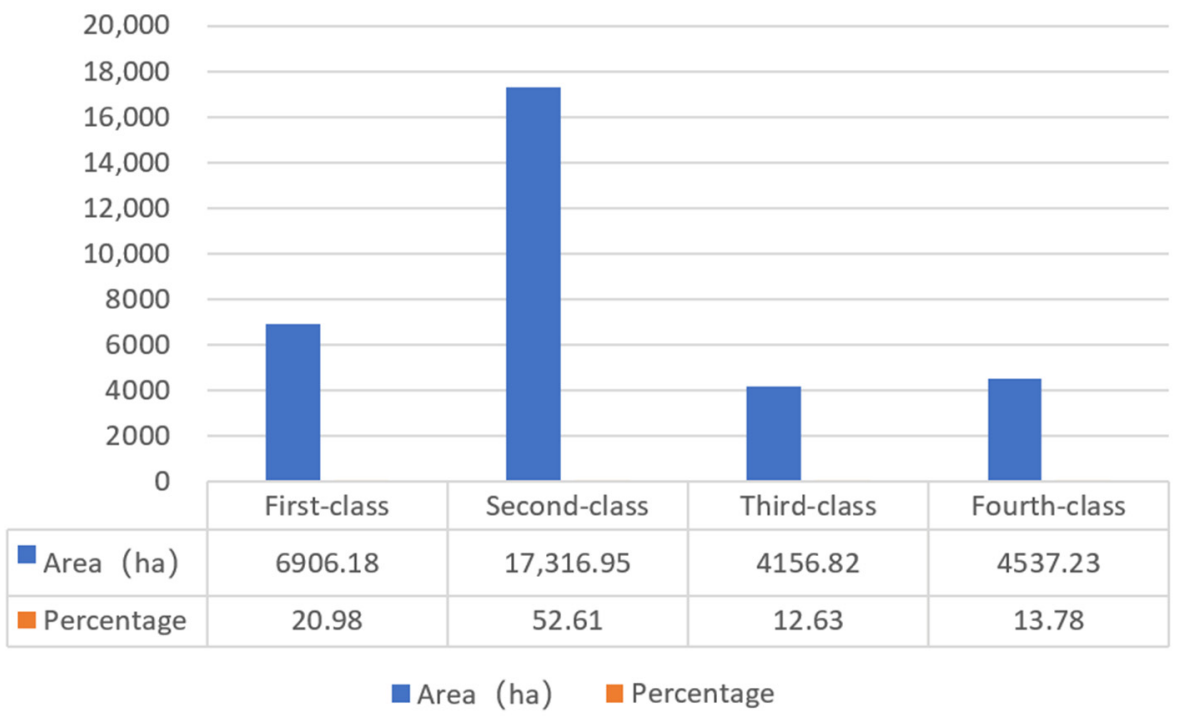

Figure 6. Distribution map of CLQ in Wen County. 
According to Table 6, there were significant differences in CLQ among towns and villages in Wen County, among which the areas of first-grade CLQ in Fantian Town, Wude Town, Huangzhuang Town, and Beileng Township took up the highest proportion of first-class land for $26.77 \%, 17.96 \%, 15.51 \%$, and $12.22 \%$, respectively. The cultivated land in the second-class land was primarily distributed in Huangzhuang Town, Zhaobao Town, Xiangyun Town, and Fantian Town, with an area ratio of $22.67 \%, 15.13 \%, 14.18 \%$, and $12.24 \%$, respectively. The third-class cultivated land mainly spreads over Zhaoxian Township, Fantian Town, Wenquan Town, and Zhaobao Town, accounting for $25.81 \%$, $24.02 \%, 14.70 \%$, and $11.49 \%$ of total land respectively. The fourth-class cultivated land is scattered among Wenquan Town, Xiangyun Town, and Heyuecun Township, taking up the proportion of $42.98 \%, 23.00 \%$, and $18.82 \%$ respectively. Among them, Fantian Town holds the largest first-class cultivated land of 1849.00 ha. The largest amount of the second-class cultivated land in Huangzhuang reaches 3925.38 ha. Zhaoxian Township takes up the highest proportion of third-class cultivated land with the area of 1073.05 ha. Wenquan Town has the largest area in the fourth-class cultivated land with 1950.15 ha.

Table 6. Distribution table of CLQ in townships of Wen County.

\begin{tabular}{|c|c|c|c|c|c|c|c|c|}
\hline Name of Town & $\begin{array}{l}\text { First-Class } \\
\text { Land/ha }\end{array}$ & $\begin{array}{l}\text { First-Class/ } \\
\text { Percentage }\end{array}$ & $\begin{array}{l}\text { Second-Class } \\
\text { Land/ha }\end{array}$ & $\begin{array}{l}\text { Second-Class/ } \\
\text { Percentage }\end{array}$ & $\begin{array}{l}\text { Third-Class } \\
\text { Land/ha }\end{array}$ & $\begin{array}{l}\text { Third-Class/ } \\
\text { Percentage }\end{array}$ & $\begin{array}{l}\text { Fourth-Class } \\
\text { Land/ha }\end{array}$ & $\begin{array}{c}\text { Fourth-Class/ } \\
\text { Percentage }\end{array}$ \\
\hline Beileng Township & 843.95 & 12.22 & 677.94 & 3.91 & 0.00 & 0.00 & 15.24 & 0.34 \\
\hline Fantian Town & 1849.00 & 26.77 & 2120.20 & 12.24 & 998.57 & 24.02 & 0.00 & 0.00 \\
\hline Huangzhuang Town & 1071.07 & 15.51 & 3925.38 & 22.67 & 0.00 & 0.00 & 9.46 & 0.21 \\
\hline Nanzhangqiang Town & 327.70 & 4.75 & 1258.93 & 7.27 & 268.11 & 6.45 & 85.01 & 1.87 \\
\hline Wenquan Town & 450.65 & 6.53 & 738.86 & 4.27 & 610.88 & 14.70 & 1950.15 & 42.98 \\
\hline Wude Town & 1240.31 & 17.96 & 1620.22 & 9.36 & 220.74 & 5.31 & 144.06 & 3.18 \\
\hline Xiangyun Town & 423.75 & 6.14 & 2455.98 & 14.18 & 414.80 & 9.98 & 1043.65 & 23.00 \\
\hline Yuecun Township & 300.36 & 4.35 & 521.35 & 3.01 & 92.98 & 2.24 & 854.07 & 18.82 \\
\hline Zhaoxian Township & 294.49 & 4.26 & 1377.86 & 7.96 & 1073.05 & 25.81 & 256.12 & 5.64 \\
\hline Zhaobao Town & 104.90 & 1.52 & 2620.22 & 15.13 & 477.68 & 11.49 & 179.46 & 3.96 \\
\hline
\end{tabular}

In accordance with Figure 7, among the townships with different productivity levels in Wen County, the first-class and second-class CLQ predominates in Beileng Township. There is no fourth-class land in Fantian Town, which holds the largest first-class cultivated land. The largest amount of the second-class cultivated land is distributed in Huangzhuang. Zhaoxian Township took up the highest proportion of third-class cultivated land. The fourth-class cultivated land of Wenquan Town was the largest area.

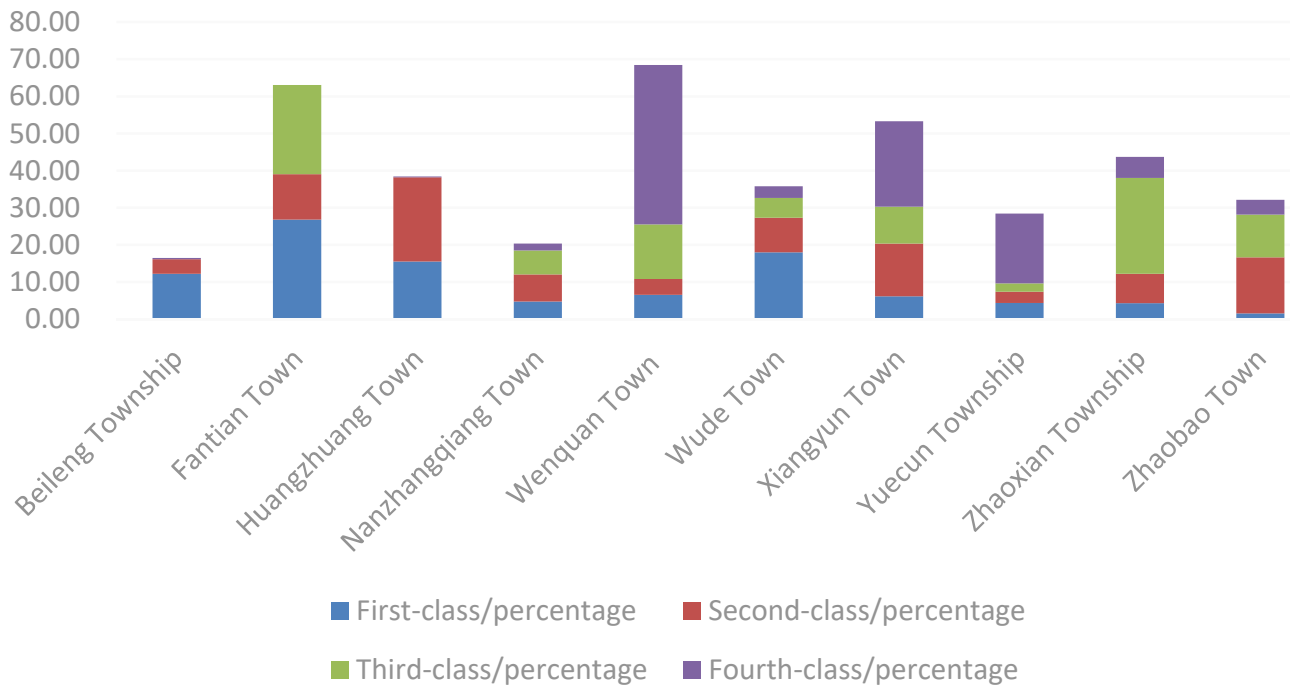

Figure 7. Distribution map of the proportion of CLQ in townships of Wen County. 
Compared with other townships, there is relatively small amount of cultivated land in Beileng Township, Nanzhangqiang Township, and Yuecun Township. Within the scope of the township, the first-class and second-class CLQ predominates in Beileng Township, which suggests the comparatively high quality of cultivated land. Although there is large quantity of cultivated land in Fantian Town, Huangzhuang Town, and Xiangyun Town, the cultivated land in Huangzhuang Town bears the highest quality with only 9.46 ha of fourth-class cultivated land and the remaining are first-class and second-class land. Without fourth-class cultivated land in the Pantian Township, there is a relatively even distribution of the first-class, second-class, and third-class cultivated land. Many large parts of Xiangyun Township's cultivated land are fourth-class land. The total area of cultivated land in Wenquan Town, Wude Town, Zhaoxian Township, and Zhaobao Town ranks in the middle. In the scope of town, the predominating cultivated land is the second-class and third-class cultivated land in Zhaoxian Township and Zhaobao Town, the fourthclass land in Wenquan Town, and the first-class and second-class cultivated land in the Wude Township.

In line with the distribution map of CLQ in Wen County (Figure 8), with the natural dyke formed by the long-term flooding of the ancient Yellow River-Qingfengling as its boundary, the CLQ in Wen County bears obvious regional differentiation characteristics, that is, the quality of northern cultivated land was higher than that in the south. The first-class and second-class areas of higher quality are mainly distributed in Huangzhuang Town, Beileng Township, Wude Town, Xiangyun Town, and Zhaobao Town. Most of them are located in the north of Qingfengling, which is the part of the Qinhe Alluvial Fan Plain with open and flat terrain and soil types of fluvo-aquic soils and small fluvo-aquic soils. This finding suggests that the area with two-in-one soils is conducive to water and fertilizer conservation owing to the cross-sectional configuration of the "loosened upper part and tight lower part" type in the interlayer type. Moreover, most soil in the region of the area is loose and well cultivated. The good basic properties of the soil are featured by the high content of soil organic matter, the cross-sectional configuration of the brick soil, strong ability to retain water and fertilizer, and a large number of earthworms and microorganisms. The third-class and fourth-class of CLQ are principally distributed in the areas in the south of Qingfengling, such as Yuecun Township, Zhaoxian Township, Wenquan Town, and Xiangyun Township. The large slope in the southern side of Qingfengling is caused by the erosion of the Yellow River. Freedom from the influence of groundwater activities at the early stage leads to the deposition of calcium carbonate. Other substances of the surface layer leached in the core soil layer form its low fertility soil. Influenced by the advance and retreat of the Yellow River, the soil type is unstable with the texture of sandy soil, which is not suitable for the survival of earthworms and microorganisms. This soil type also bears the low ability to preserve water and fertilizer, backward agricultural production conditions, and the low biological activities in the field surveys in Southern Xiangyun Township and Yuecun Township and Wenquan Town.

It can be seen that due to the different geographical location, farmland infrastructure, and soil characteristics of each field, the production potential of the land is affected. The main factors that affect the land are the soil profile configuration, soil texture, soil organic matter, soil organisms, and irrigation and drainage facilities [71]. The new unified survey and evaluation method of CLQ more conveniently analyzed the relationship between CLQ grades, soil types, and land use, which not only provided a scientific basis for the transformation of medium and low yield fields, the rational use, and management of cultivated land resources, but also laid a foundation for the sustainable evaluation of land resources in Wen County in the future. In the process of improving land grain production capacity, in addition to natural macro factors such as light, temperature, water, air, and heat, which are relatively difficult to change, it is necessary to focus on improving other influencing factors that can increase land production efficiency and reduce production costs, such as irrigation facilities [72]. In addition, the issue of sustainable use of cultivated land should also be considered. It is necessary to maintain the vitality of cultivated land 
soil organisms and reduce the intensity of soil utilization. At the same time, the soil should be protected from heavy metal pollution and maintain soil health.

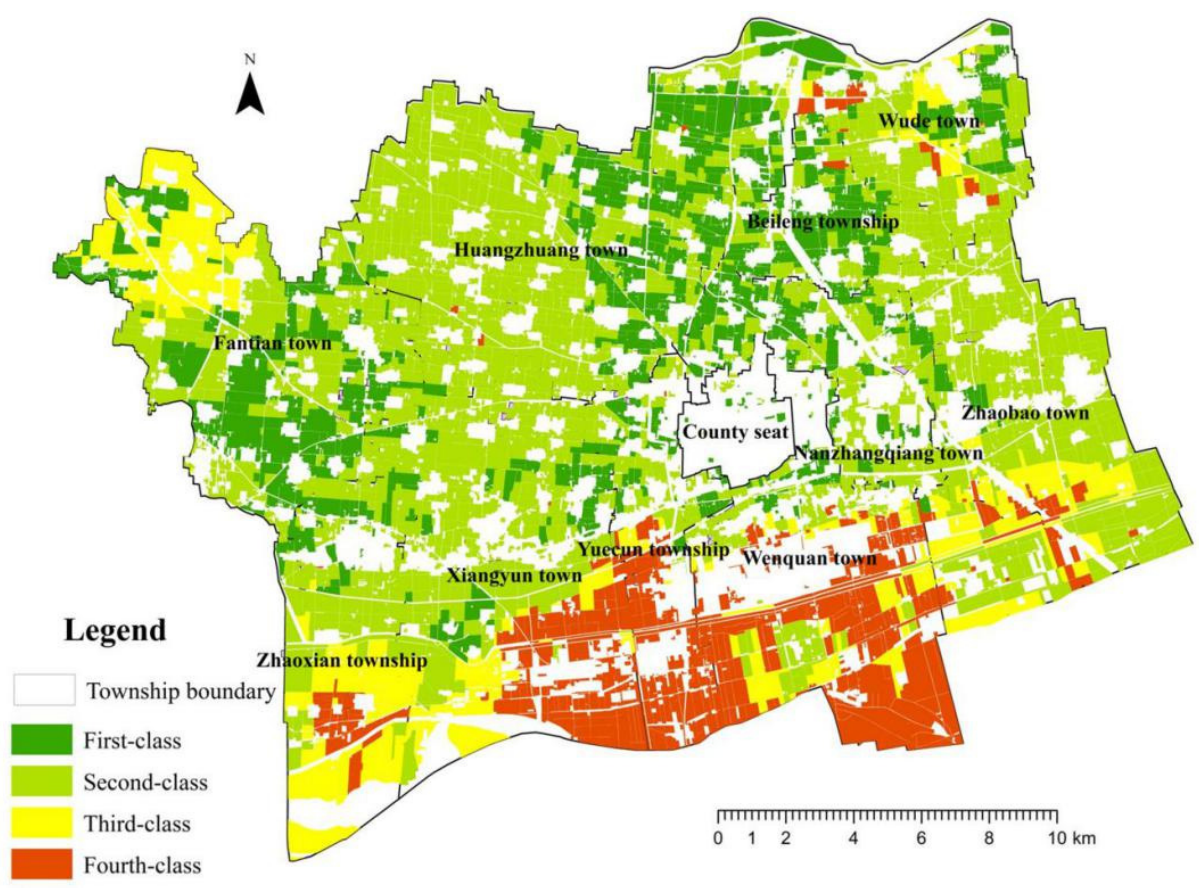

Figure 8. Wen County's CLQ class distribution map.

\subsection{Comparative Analysis with Results of National Utilization Gradation}

It must be acknowledged that the accuracy of the evaluation results of CLQ will directly affect the application of the results, and it is a challenge to scientifically validate the reliability of a land quality grading system. In order to verify the reliability of the new method, the study uses two methods, including the spatial pattern comparison method and crop yield verification method $[5,24]$.

In the original national evaluation of agricultural land use, Wen County's utilization gradation ranges from fourth class to seventh class (Figure 9), suggesting a relatively high grade as a whole. Among them, the largest amount of fifth-class land accounted for $62.52 \%$ of the county's cultivated land, followed by sixth-class land, which takes a proportion of $28.47 \%$ of the county's cultivated land. The fourth-class and seventhclass land covered relatively small area, accounting for $7.17 \%$ and $1.84 \%$ of the county's cultivated land, respectively. Comparing Wen County's CLQ distribution map and that of national utilization gradation, the low and medium CLQ in the county bore the same distribution trends as a whole. However, obvious differences are noted in the cultivated land in the northern part of Fantian Town. Although the technical facilities are complete, the overuse of soil caused by too many pesticides and fertilizers sprayed in some fields threatens the living space of soil organisms, resulting in the low biological activity of cultivated land [73]. The new index of CLQ evaluation gradation is employed to fit the original index of China's utilization gradation, which has the moderate fitting degree with the index fitting of $\mathrm{R}^{2}=0.3027$ because of the different evaluation indicators selected and different evaluation method and evaluation result gradation. Nevertheless, the consistency between the two bears the spatial distribution trend of CLQ, that is, the northern cultivated land has higher quality than the southern cultivated land bounded by Qingfengling. The biological activity of cultivated land and the indicators of soil environmental conditions have a dramatic influence on the quality of cultivated land. 


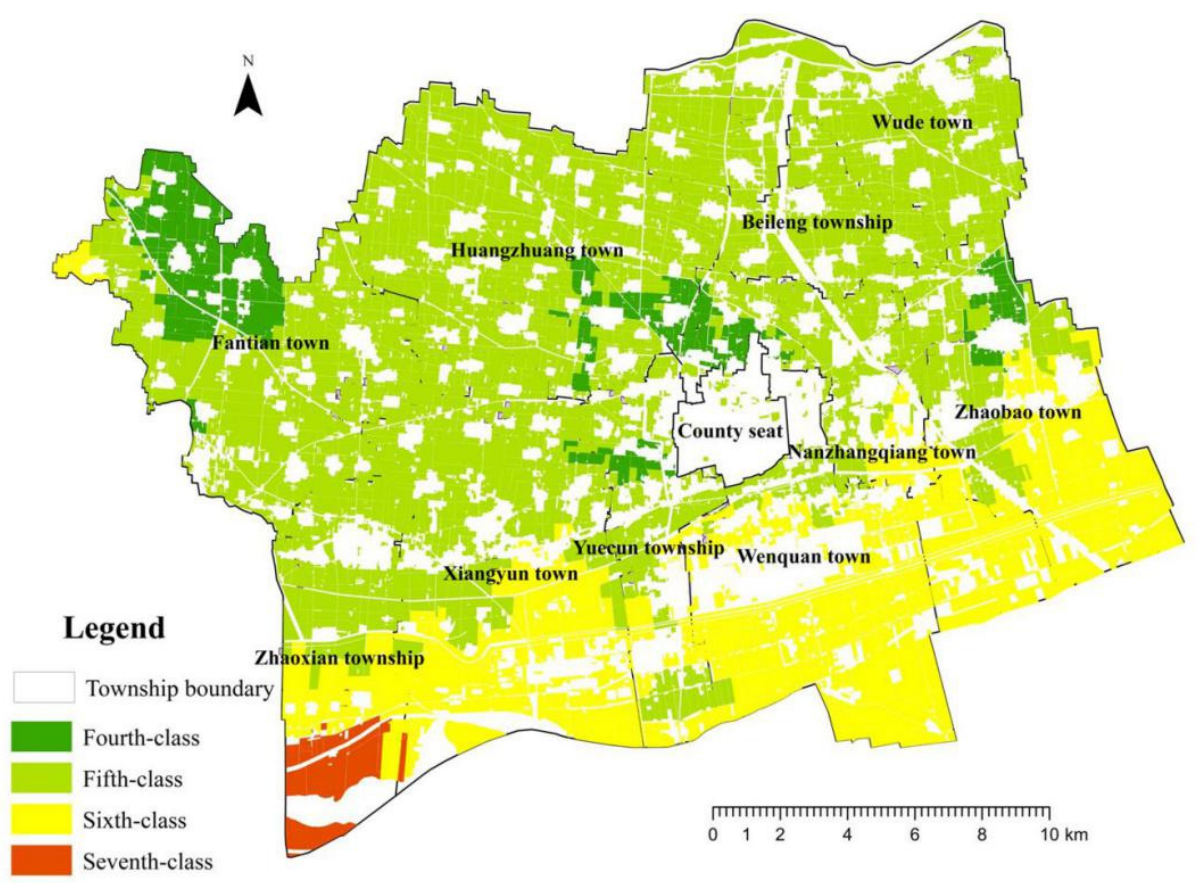

Figure 9. Distribution map of Wen County's national utilization class.

\subsection{Fitting with Measured Data of Grain Yield}

Cultivated land is a land use system that specifically meets the needs of food, and its obvious use goal is to provide crop production capacity. As the core of CLQ, food production capacity is an important manifestation of CLQ and the basic guarantee of national food security. Therefore, it is feasible to use the actual grain yield to verify the evaluation results of CLQ. According to the "Statistical Reporting System for Agriculture, Forestry, Animal Husbandry and Fisheries" formulated by the National Bureau of Statistics of the People's Republic of China, the actual sampling survey plan for the summer and autumn grain yields in Wen County is formulated in combination with the sampling survey system for the grain yield in Henan Province. The specific operations are as follows:

(1) Sampling: on the basis of the production results of prediction, the method of equidistant sampling at half-distance starting point is adopted to select four measured plots.

(2) Actual measurement: among the measured sample plots, three samples are uniformly cut to obtain sample gross quality data and net sample quality.

(3) Calculation: the annual yield of the measured standard annual yield of summer and autumn grain in Wen County is inferred from the national standard false hybrid rate, measured false hybrid rate, and deduction loss per acre.

In this research, the above method was utilized to sample and survey the actual annual standard yield of 40 plots in Wen County in 2017 (with the spatial information shown in Figure 10). The regression analysis is applied to the annual standard crop yield of these 40 measured plots and the trial CLQ index to acquire the results illustrated in Figure 11. The square value of the judgment coefficient $R$ was 0.7127 , which indicates a significant positive correlation trend between CLQ index and crop yield. The CLQ evaluation method demonstrated the production capacity of local crops. 


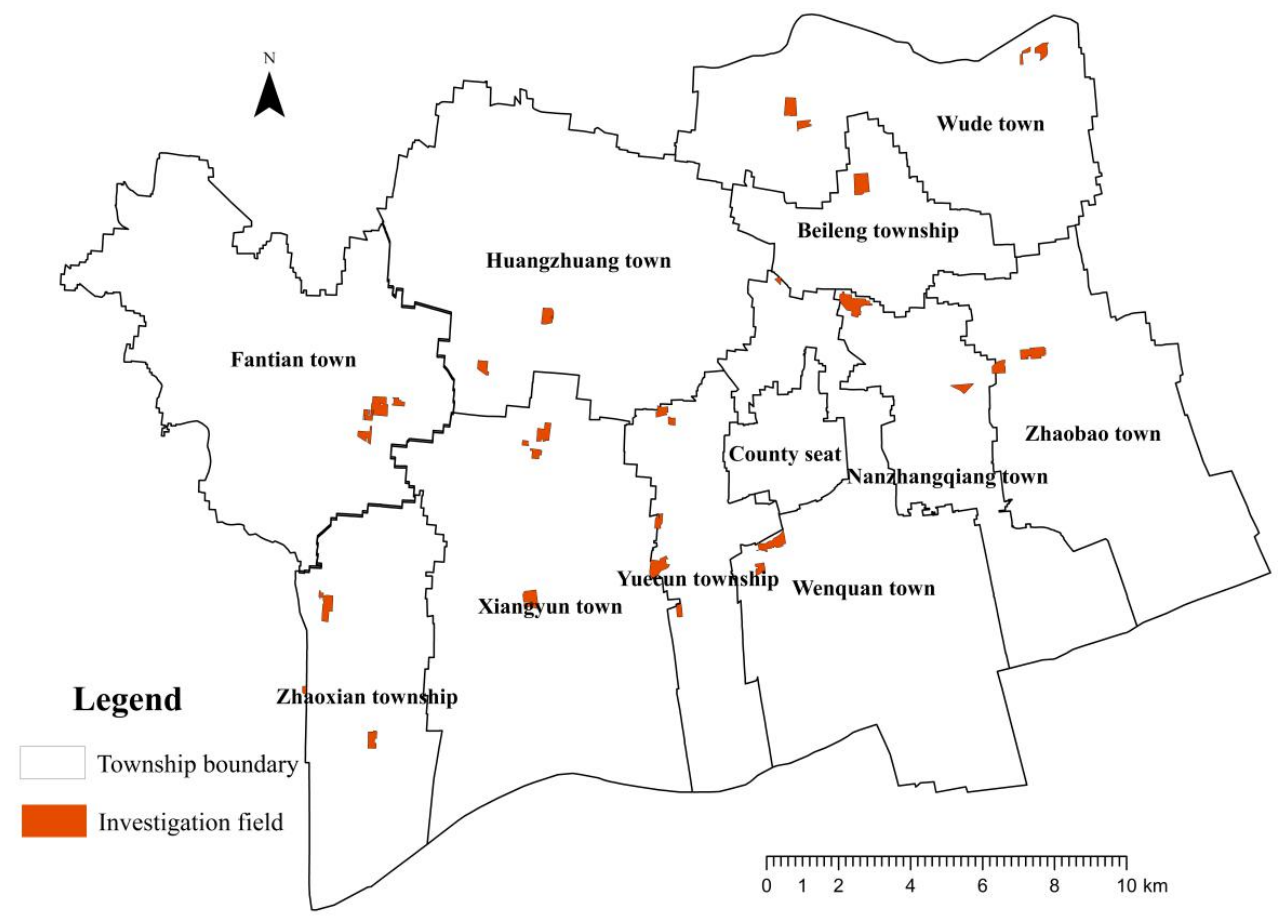

Figure 10. Spatial location map of investigation fields in Wen County.

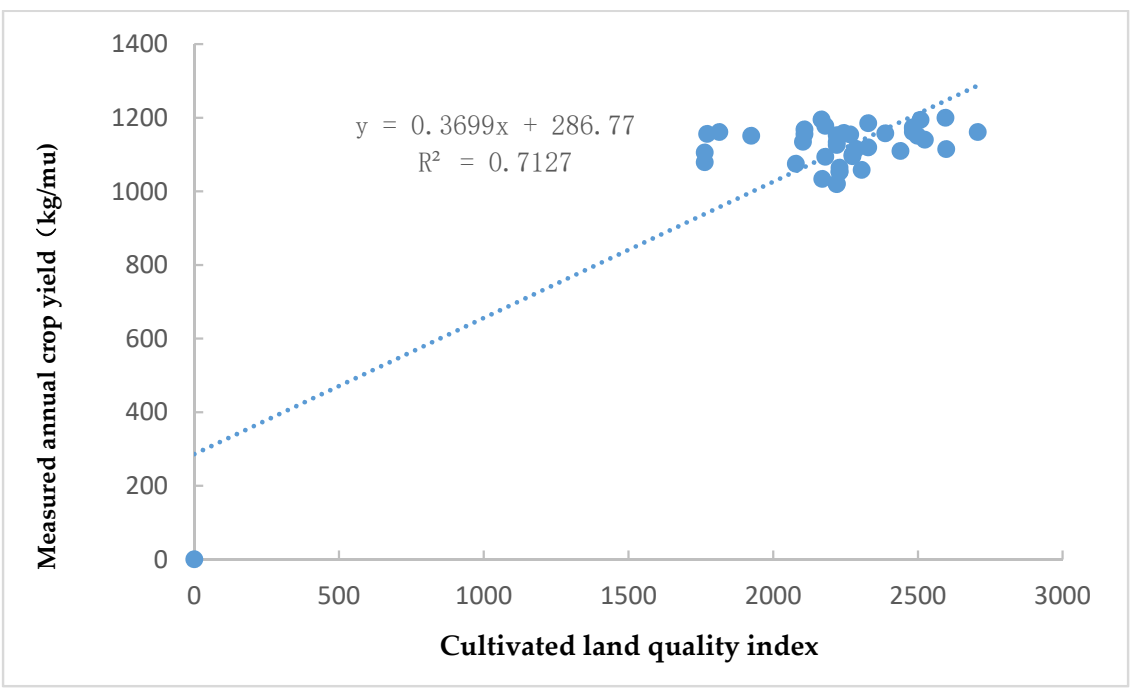

Figure 11. Scatter plot of the CLQ index and measured grain yield.

\section{Discussion}

Cultivated land resource management should pay attention to the relationship between land use, evaluation, and protection, identify the key processes of cultivated land use through CLQ evaluation, and formulate cultivated land resource protection measures according to local conditions with the help of biological, chemical, and physical engineering methods. At present, the relevant land resource management departments in China have established evaluation standards based on different purposes, resulting in duplication and cumbersome work processes, and evaluation results cannot be compared with each other. There is an urgent need to establish a unified CLQ survey and evaluation method to compare and integrated the farmland production capacity of the production capacity and CLQ and the geochemical element level of the Ministry of Natural Resources, the soil improvement of the Ministry of Agriculture and Rural Affairs, the cultivation of cultivated land, and the soil environment of the Ministry of Environmental Protection. According to 
the results, in order to increase the food production potential of the cultivated land in Wen County, the Ministry of Agriculture and Rural Affairs can increase the soil organic matter content by planting green manure crops, returning straw to the field, and rational fertilization [74]. The Ministry of Ecology and Environment can actively and effectively supervise the pollution and destruction of cultivated land. The Ministry of Natural Resources can use engineering construction measures to improve the farmland irrigation and drainage system, strengthen the construction of water source projects, carry out the construction of irrigation and drainage facilities, build and repair farmland protection forest nets in areas prone to soil erosion, and strengthen the construction of farmland protection and ecological environment maintenance.

With the development of the times, society continues to put forward new requirements. In order to meet the needs of the public, the evaluation of CLQ keeps pace with the times and constantly adds new content [75]. Mainly experienced suitability evaluation [76], productivity evaluation $[77,78]$, comprehensive evaluation of suitability and productivity [79], land health evaluation [80], soil sustainability evaluation [81], and comprehensive evaluation of the production, ecology, and health [82] stage. In the 1980s, the land evaluation and site evaluation (LESA) system established by the Soil Conservation Service (SCS) of the United States emphasized the important role of socioeconomic conditions in the evaluation of CLQ [83]. This study also selected the drainage conditions, irrigation capacity, and the degree of farmland forestry to reflect the socioeconomic conditions of farmland. In the past decade, China's agricultural development has shifted from pursuing grain production to focusing on the ecological security of cultivated land [84]. Therefore, ecological factors need to be considered in the evaluation of CLQ [85]. This study draws on existing research results $[86,87]$, and selects soil earthworms and soil microbial biomass carbon to characterize the ecological quality of cultivated land. Nonetheless, China has a vast territory with great distinction of the natural conditions in various regions. If unified indicators, indicator grading, and indicator assignments are applied, such regional differences will be masked, resulting in unpractical situations. In the future, indicators should be continuously optimized and improved. Indicators that reflect the characteristics of regional CLQ should also be selected on the basis of the background conditions of the evaluation unit. The determination of indicator weights is an important part of CLQ evaluation. It is worth explaining that the paper uses a combination of qualitative and quantitative methods to determine the weights. In practice, further application verification is needed, and the weight determination method is continuously improved.

In the 3rd survey, the county-level tasks are to update and improve the existing results on the basis of the investigation and evaluation of the cultivated land classification and classification and implement the latest achievements of the cultivated land gradation and evaluation on the map of current land use to construct a special database for the gradation of cultivated land. Under this context, the pattern spot of cultivated land determined by the 3rd survey is taken as the evaluation unit, in combination of the content of the cultivated land type and cultivated land planting attributes of the 3rd survey. The rational employment of the data of the 3rd survey to carry out the unified investigation and evaluation trial of CLQ at the county scale refines the differences in CLQ in local areas. It not only conforms to the policy guidance of the Ministry of Natural Resources but also keeps up with the development trend of the times, and provides technical support for the comprehensive evaluation of the quality of cultivated land and a reference for the accuracy of the pattern spot of cultivated land in the 3rd survey. Seeing that irrigated land is the sole cultivated land type in Wen County, the investigation and evaluation of the quality of cultivated land is not influenced by the type of cultivated land in the county. Additionally, in the 3rd survey of cultivated land planting attributes in Wen County, grain and non-grain planting areas accounts for $0.38 \%$; non-cultivated areas, $0.06 \%$; non-food crop areas, $0.15 \%$; and general planted areas, $99.4 \%$. The small difference in cultivated land planting attributes within the county scale exerts less influence on CLQ. In the future, the adaptability and rationality of this method in areas with significant differences in cultivated land types and 
cultivated land planting attributes must be further explored so as to truly establish and improve the evaluation system of CLQ.

In the process of the evaluation, the mean value at the county scale is taken as a benchmark for the biological activity indicator of cultivated land, so the evaluation results are comparable at the county scale, which requires the exploration and formulation of the provincial or the national standard in the future. Moreover, the soil characteristics and tillage conditions are selected from the indicators in the "Cultivated Land Quality Gradation" (GB/T 33469-2016) of the Ministry of Agriculture and Rural Affairs, but their biodiversity and cleanliness are qualitative indicators that fail to be applied reasonably. The soil earthworms and soil microbial carbon selected for the bioactive element index in the article are acquired from field sampling surveys and are applied at the field scale at present. Consequently, the grading standards of various indicators and the final gradation standards should be further discussed to achieve the goal of national comparison.

Currently, under the frequent food safety problems and the complicated international environment, although the highly intensive utilization of cultivated land has continuously increased food production, it has also caused a series of ecological and environmental problems and the resulting crop quality problems, such as "cadmium rice". These problems threaten the sustainable use of cultivated land systems, national food security, and human health. The demand for cultivated land in human society has changed from the high yield and high efficiency at the very beginning to the comprehensive demand for stable production capacity, clean production environment, green products, and sustainable utilization of cultivated land system. From focusing on CLQ to the healthy quality of cultivated land, we need to continuously pay attention to the continuous and stable production capacity of cultivated land, crop production environment, and the influence of produced agricultural products on human health, with an emphasis on the stability of the cultivated land system. For future research, we should combine the actual situation and requirements of China's cultivated land resource management, rationalize the natural attributes and management goals of cultivated land at different spatial scales, and continue to carry out research on the evaluation of cultivated land health quality at different scales. Future research should not only focus on the productivity of cultivated land but also pay more attention to the sustainable utilization of cultivated land resources. The cultivated land resource management system in China, the parcel of field represents the grassroots evaluation unit and the largest uniform unit for farmers to carry out production activities. The county represents a common project unit and a common scale for the sustainable utilization and management of cultivated land resources. As for the macro scale of province and nation, no direct evaluation plan is available. Consequently, the four scales of field, county, province, and country must be explored. For instance, at the national scale, the short and weak areas of cultivated soil health in the country are charted to research on corresponding optimization and conservation strategies. At the provincial scale, research on the control measures of provincial cultivated land health quality should be conducted on the basis of the identification of geomorphologic types, tillage methods, intensive utilization, environmental constraints, and other factors threatened by soil health. At the county scale, the overall condition and spatial variation of cultivated land health quality should be explored under different planting systems and intensities to propose cultivated land management and protection strategy of the county in a typical area. At the field scale, combined with different cultivated land management scenarios, the constraints of soil health and the degree of its threats in cultivated land must be identified to establish a cultivated land management model to maintain its health. The above plans are to be implemented to promote the rationalization and standardization of cultivated land use and realize the maximum and optimal function of cultivated land in the future.

\section{Conclusions}

This study clarified the connotation, composition, characteristics, and influencing factors of CLQ. At the county level, CLQ is defined as the food production capacity 
of cultivated land to support the construction of modern agricultural production and maintain its own safety and sustainable utilization. Broaden the practical working path of the investigation and evaluation of CLQ. It selects six elements of cultivated land climate conditions, including soil characteristics, tillage conditions, cultivated land type attributes, environmental conditions, and biological activity from the three dimensions of agricultural climate, productivity potential, and physical condition components of cultivated land to optimize the indicators of the existing evaluation system. This study also proposes a simple, practical, and operable unified evaluation system for the CLQ that meets the demands of national engineering for multidepartmental inclusion and coordination. The reasonable employment of cultivated land survey and evaluation data contributes to realize the sharing of data on platforms, save manpower and capital investment, improve the practical connection of supervision and management of cultivated land protection in different departments, and meet the current requirements of cultivated land protection and management. The unified evaluation system bears certain demonstrative, guiding, and innovative features.

In this study, according to the restrictive and non-additive principle of the cultivated land system, the weighted sum method is first utilized to calculate the cultivated land soil characteristics, cultivation conditions, and cultivated land type attribute coefficients, with the climatic production potential of cultivated land as the core. The environmental condition and biological activity coefficients are then calculated through the application of the " $1+X$ " model. Subsequently, the light temperature/climate production potential index is gradually revised with the coefficients of each factor and the yield ratio to gain the CLQ index in the end. With the work ideas of agricultural land gradation adopted, the investigation and evaluation of the county-level CLQ is further optimized. It can provide reference for the establishment of comprehensive evaluation index system of CLQ in other similar countries and regions.

In line with the indicator system of CLQ survey and evaluation, a combination of qualitative and quantitative analysis methods is applied in this study to evaluate CLQ in Wen County, the major grain producing area in Henan Province. The evaluation results demonstrate that the high-quality cultivated land is mainly distributed in Huangzhuang Town, Beileng Township, Wude Town, Xiangyun Town, and Zhaobao Town in the north of Qingfengling, which bears the open and flat area, loose soil, and good cultivability. The low-quality cultivated land is primarily scattered in most area in the south of Qingfengling, including Yuecun Township, Zhaoxian Township, Wenquan Town, Xiangyun Township, and the northern area of Fantian Town. In the south of Qingfengling lies the floodplain of the Yellow River with low fertile soil, sandy soil texture, and backward agricultural production conditions. As a result, this part of the area can be regarded as a land remediation project area in Wen County that needs to be rectified and upgraded in the future.

Author Contributions: Conceptualization, R.Z. and K.W.; methodology, R.Z. and X.L.; validation, R.Z. and X.L.; formal analysis, R.Z.; X.L. and N.G.; investigation, R.Z. and M.Y.; resources, K.W.; data curation, R.Z.; X.L. and N.G.; writing-original draft preparation, R.Z.; writing review and editing, K.W. and M.Y.; visualization, R.Z.; supervision, K.W.; project administration, K.W.; funding acquisition, K.W. All authors have read and agreed to the published version of the manuscript.

Funding: This study was supported by the National Key R\&D Program of China (No.2018YFE0107000, 2017YFF0206800) and the National Natural Science Foundation of China (41371226).

Institutional Review Board Statement: Not applicable.

Informed Consent Statement: Not applicable.

Data Availability Statement: The datasets used and/or analyzed during the current study are available from the corresponding author on reasonable request.

Acknowledgments: Thanks for research assistance from Wenju, Yun, Leina Zhang and Feng Chen. Insightful and constructive comments of the anonymous reviewers are appreciated.

Conflicts of Interest: The authors declare no conflict of interest. 


\section{References}

1. FAO. World Agriculture: Towards 2030/2050-Interim Report. 2006, Rome. Available online: http:/ /www.fao.org/fileadmin/ user_upload/esag/docs/Interim_report_AT2050web.pdf (accessed on 7 June 2006).

2. Bai, Z.-G.; Dent, D.-L.; Olsson, L.; Schaepman, M.E. Proxy global assessment of land degradation. Soil Use Manag. 2008, 24, 223-234. [CrossRef]

3. Lambin, E.F.; Meyfroidt, P. Global land use change, economic globalization, and the looming land scarcity. Proc. Natl. Acad. Sci. USA 2011, 108, 3465-3472. [CrossRef]

4. Barbier, E.B. Poverty, development, and environment. Environ. Dev. Econ. 2010, 15, 635-660. [CrossRef]

5. Liu, L.-M.; Zhou, D.; Chang, X.; Lin, Z.-L. A new grading system for evaluating China's cultivated land quality. Land Degrad Dev. 2020, 31, 1482-1501. [CrossRef]

6. Smith, V.H.; Glauber, J.W. Trade, policy, and food security. Agric. Econ. 2020, 51, 159-171. [CrossRef]

7. Pan, H.; Liang, J.; Zhao, Y.; Li, F. Facing the 3rd national land survey (cultivated land quality): Soil survey application for soil texture detection based on the high-definition field soil images by using perceptual hashing algorithm (phash). J. Soil Sediment. 2020, 20, 3427-3441. [CrossRef]

8. Wu, K.-N.; Zhao, R.; Zhao, H.-F. Thoughts on the current survey and evaluation of the quality of cultivated land in my country. China Land. 2018, 3, 19-20. (In Chinese)

9. Wu, Y.P.; Yun, W.J.; Zou, R. Model for calculation of cultivated land productivity. Trans. Chin. Soc. Agric. Eng. 2008, 24, 108-113. (In Chinese)

10. Luo, H.-Y. Monitoring research for the "Trinity" of cultivated farmland in the north bay area of Guangxi under the new normality. Chin. J. Agric. Resour. Reg. Plan. 2018, 39, 139-145.

11. Castañeda-Ccori, J.; Bilhaut, A.-G.; Mazé, A.; Fernández-Manjarrés, J. Unveiling Cacao Agroforestry Sustainability through the Socio-Ecological Systems Diagnostic Framework: The Case of Four Amazonian Rural Communities in Ecuador. Sustainability 2020, 12, 5934. [CrossRef]

12. Hao, L.-N.; Su, X.-L.; Singh, V.P.; Zhang, L.; Zhang, G.-X. Suitable oasis and cultivated land scales in arid regions based on ecological health. Ecol. Indic. 2019, 102, 33-42. [CrossRef]

13. Wu, C.; Liu, Q.; Ma, G.; Liu, G.; Yu, F.; Huang, C.; Zhao, Z.; Liang, L. A Study of the Spatial Difference of the Soil Quality of The Mun River Basin during the Rainy Season. Sustainability 2019, 11, 3423. [CrossRef]

14. Gustavo, P.V.; Fabiane, M.V.; Karina, M.; Karina, M.V.C.P. Soil quality: Evaluation of on-farm assessments in relation to analytical index. Soil Till. Res. 2020, 198, 104565. [CrossRef]

15. Shao, G.-D.; Ai, J.-J.; Sun, Q.-W.; Hou, L.-Y.; Dong, Y.-F. Soil quality assessment under different forest types in the Mount Tai, central Eastern China. Ecol. Indic. 2020, 115, 106439. [CrossRef]

16. Moebius-Clune, B.N.; Moebius-Clune, D.J.; Gugino, B.K.; Idowu, O.J.; Schindelbeck, R.R.; Ristow, A.J.; Van, E.H.M.; Thies, J.E.; Shayler, H.A.; McBride, M.B.; et al. Comprehensive Assessment of Soil Health. In The Cornell Framework Manual, 3rd ed.; Cornell University: Geneva, NY, USA, 2016.

17. Doran, J.W.; Zeiss, M.R. Soil health and sustainability: Managing the biotic component of soil quality. Appl. Soil Ecol. 2000, 15, 3-11. [CrossRef]

18. Fine, A.K.; Van, E.H.M.; Schindelbeck, R.R. Statistics, Scoring Functions, and Regional Analysis of a Comprehensive Soil Health Database. Soil Sci. Soc. Am. J. 2017, 81, 589-1344. [CrossRef]

19. Nunes, M.R.; Karlen, D.L.; Moorman, T.B. Tillage Intensity Effects on Soil Structure Indicators-A US Meta-Analysis. Sustainability 2020, 12, 2071. [CrossRef]

20. Zhang, Y.-N.; Long, H.-L.; Tu, S.-S.; Ge, D.-Z.; Ma, L.; Wang, L.-Z. Spatial identification of land use functions and their tradeoffs/synergies in China: Implications for sustainable land management. Ecol. Indic. 2019, 107, 105550. [CrossRef]

21. Xue, Z.-C.; Zhen, L.; Miah, M.G.; Shoyama, K. Impact assessment of land use functions on the sustainable regional development of representative Asian countries-A comparative study in Bangladesh, China and Japan. Sci.Total Environ. 2019, 694, 133689. [CrossRef] [PubMed]

22. Han, H.-B.; Zhang, X.-Y. Exploring environmental efficiency and total factor productivity of cultivated land use in China. Sci. Total Environ. 2020, 726, 138434. [CrossRef]

23. Wang, S.-C.; Wang, J.-Z.; Zhao, Y.-W.; Ren, Y.; Xu, M.-G.; Zhang, S.-X.; Lu, C.-A. Assessment of the contribution percentage of inherent soil productivity of cultivated land in China. J. Integr. Agric. 2019, 18, 2619-2627. (In Chinese) [CrossRef]

24. Zhao, C.; Zhou, Y.; Li, X.; Xiao, P.; Jiang, J. Assessment of Cultivated Land Productivity and Its Spatial Differentiation in Dongting Lake Region: A Case Study of Yuanjiang City, Hunan Province. Sustainability 2018, 10, 3616. [CrossRef]

25. Zou, L.-L.; Liu, Y.-S.; Yang, J.-X.; Yang, S.-F.; Wang, Y.-S.; Zhi, C.; Hu, X.-D. Quantitative identification and spatial analysis of land use ecological-production-living functions in rural areas on China's southeast coast. Habitat Int. 2020, 100, 102182. [CrossRef]

26. Li, M.; Fu, Q.; Singh, V.P.; Liu, D.; Li, T.-X.; Li, J. Sustainable management of land, water, and fertilizer for rice production considering footprint family assessment in a random environment. J. Clean Prod. 2020, 258, 120785. [CrossRef]

27. Yang, R.-M.; Minasny, B.; Ma, Y.-X.; Field, D.; McBratney, A.; Wu, C.-F. A preliminary soil security assessment of agricultural land in middle-eastern China. Soil Use Manage. 2018, 34, 584-596. [CrossRef]

28. Kidd, D.; Field, D.; Mcbratney, A.; Webb, M. A preliminary spatial quantification of the soil security dimensions for Tasmania. Geoderma 2018, 322, 184-200. [CrossRef] 
29. Koch, A.; McBratney, A.; Lal, R. Global soil week: Put soil security on the global agenda. Nature 2012, 492, 186. [CrossRef]

30. Mcbratney, A.; Field, D.J.; Koch, A. The dimensions of soil security. Geoderma 2014, 213, 203-213. [CrossRef]

31. Gao, L.-L.; Zhang, C.; Lv, Y.-H.; Chen, W.-L.; Yun, W.-J.; Ma, J.-N. Construction and Application of Multi-factor Cultivated Land Health Productivity Evaluation System. Trans. Chin. Soc. Agric. Mach. 2020, 51, 215-222. (In Chinese)

32. Zhang, X.-D.; Wu, K.-N.; Zhao, R.; Yang, Q.-J. Evaluation of Healthy Productivity of Cultivated Land at County Scale. Res. Soil Water Conserv. 2020, 27, 294-300. (In Chinese)

33. Peng, Y.; Qian, J.; Ren, F.; Zhang, W.; Du, Q. Sustainability of Land Use Promoted by Construction-to-Ecological Land Conversion: A Case Study of Shenzhen City, China. Sustainability 2016, 8, 671. [CrossRef]

34. Zong, W.-W.; Cheng, L.; Xia, N.; Jiang, P.-H.; Wei, X.-Y.; Zhang, F.-L.; Jin, B.-X.; Zhou, J.-S.; Li, M.-C. New technical framework for assessing the spatial pattern of land development in Yunnan Province, China: A "production-life-ecology" perspective. Habitat Int. 2018, 80, 28-40. [CrossRef]

35. Ye, S.-J.; Song, C.-Q.; Shen, S.; Gao, P.-C.; Cheng, C.-X.; Cheng, F.; Wan, C.-J.; Zhu, D.-H. Spatial pattern of arable land-use intensity in China. Land Use Policy 2020, 99, 104845. [CrossRef]

36. Krystyna, K.; Hubert, K.; Renata, M.B.; Monika, M.; Przemysław, L. Conversion of agricultural and forest land to other purposes in the context of land protection: Evidence from Polish experience. Land Use Policy 2020, 95, 104614. [CrossRef]

37. Song, Y.-N.; Hou, D.-Y.; Zhang, J.-L.; O'Connor, D.; Li, G.-H.; Gu, Q.-B.; Li, S.-P.; Liu, P. Environmental and socio-economic sustainability appraisal of contaminated land remediation strategies: A case study at a mega-site in China. Sci. Total Environ. 2018, 610-611, 391-401. [CrossRef]

38. Bedano, J.C.; Domínguez, A. Large-Scale Agricultural Management and Soil Meso- and Macrofauna Conservation in the Argentine Pampas. Sustainability 2016, 8, 653. [CrossRef]

39. Wen, L.-Y.; Kong, X.-B.; Xin, Y.-N.; Sun, X.-B. Evolution of cultivated land quality connotation and its recognition. Trans. Chin. Soc. Agric. Eng. 2019, 35, 234-242. (In Chinese)

40. Cao, M.; Zhu, Y.; Lü, G.; Chen, M.; Qiao, W. Spatial Distribution of Global Cultivated Land and Its Variation between 2000 and 2010, from Both Agro-Ecological and Geopolitical Perspectives. Sustainability 2019, 11, 1242. [CrossRef]

41. Xiao, L.; Yang, X.; Cai, H.; Zhang, D. Cultivated Land Changes and Agricultural Potential Productivity in Mainland China. Sustainability 2015, 7, 11893-11908. [CrossRef]

42. Yu, J.-X.; Wei, W.; Liao, X.-H.; Peng, Y.; Liao, L.-J.; Zhao, Y.-L. Modified method for gradation on agricultural land quality in land remediation project areas. J. China Agric. Univ. 2019, 24, 156-164. (In Chinese) [CrossRef]

43. Zhuang, S.; Lu, X. Environmental Risk Evaluation and Source Identification of Heavy Metal(loid)s in Agricultural Soil of Shangdan Valley, Northwest China. Sustainability 2020, 12, 5806. [CrossRef]

44. Yu, X.; Mu, C.; Zhang, D. Assessment of Land Reclamation Benefits in Mining Areas Using Fuzzy Comprehensive Evaluation. Sustainability 2020, 12, 2015. [CrossRef]

45. Yuan, L.; Yang, K.; Chen, G.-P. Quantifying Evaluation and Grading of Cultivated Land Fertility: A Case Study of Huaping, China. Pol. J. Environ. Stud. 2019, 28, 2685-2696. [CrossRef]

46. Xia, Z.-Q.; Peng, Y.-P.; Liu, S.-S.; Liu, Z.-H.; Wang, G.-X.; Zhu, A.-X.; Hu, Y.-M. The Optimal Image Date Selection for Evaluating Cultivated Land Quality Based on Gaofen-1 Images. Sensors (Basel) 2019, 19, 4937. [CrossRef]

47. Vaezi, A.R.; Hasanzadeh, H.; Cerdà, A. Developing an erodibility triangle for soil textures in semi-arid regions, NW Iran. Catena 2016, 142, 221-232. [CrossRef]

48. Grunwald, S.; Thompson, J.A.; Boettinger, J.L. Digital soil mapping and modeling at continental scales: Finding solutions for global issues. Soil Sci. Soc. Am. J. 2011, 75, 1201-1213. [CrossRef]

49. Liu, Y.-S. Research on the urban-rural integration and rural revitalization in the new era in China. Acta Geogr. Sin. 2018, 73, 637-650. (In Chinese) [CrossRef]

50. Du, G.-M.; Liu, Y.-S.; Yu, F.-R.; Liu, M.; Zheng, H.-Y. Evolution of concepts of cultivated land quality and recognition. Trans. Chin. Soc. Agric. Eng. 2016, 32, 243-249. (In Chinese) [CrossRef]

51. Kuang, L.-H.; Ye, Y.-C.; Zhao, X.-M.; Guo, X. Evaluation and Obstacle Factor Diagnosis of Cultivated Land System Security in Yingtan City Based on the Improved TOPSIS Method. J. Nat. Resour. 2018, 33, 1627-1641. (In Chinese) [CrossRef]

52. Li, H.; Zhang, X.-L.; Zhang, X.; Wu, Y.-Z. Utilization benefit of cultivated land and land institution reforms: Economy, society and ecology. Habitat Int. 2018, 77, 64-70. [CrossRef]

53. Wang, L.-C.; Wang, G.-Q.; Yang, J.-B.; Yang, J.-F.; Tian, Y. Spatial interpolation method of crop productive potentiality for the classification of agricultural land. Trans. Chin. Soc. Agric. Eng. 2006, 2, 89-93. (In Chinese) [CrossRef]

54. Qiu, W.-L.; Wang, J.; Guo, W.-X. Elements for the Quality of Agricultural Land:Reading of the Procedure for Agricultural Land Grading. China Dev. 2012, 12, 54-57. (In Chinese) [CrossRef]

55. Wright, L.-E.; Zitzmann, W.; Young, K.; Googins, R. LESA-agricultural Land Evaluation and Site Assessment. J. Soil Water Conserv. 1983, 38, 82-86. [CrossRef]

56. Zhu, Y.-G.; Meharg, A.A. Protecting global soil resources for ecosystem services. Ecosyst. Health Sustain. 2016, 1, 1-4. [CrossRef]

57. Warkentin, B.P. The changing concept of soil quality. J. Soil Water Conserv. 1995, 50, 226-228. [CrossRef]

58. Wei, L.; Luo, Y.; Wang, M.; Su, S.-L.; Pi, J.-H.; Li, G. Essential fragmentation metrics for agricultural policies: Linking landscape pattern, ecosystem service and land use management in urbanizing China. Agric. Syst. 2020, 182, 102833. [CrossRef] 
59. Fatemeh, K.; Arjen, Y.H.; Rick, J.H. Hogeboom, Reducing food waste and changing cropping patterns to reduce water consumption and pollution in cereal production in Iran. J. Hydrol. 2020, 586, 124881. [CrossRef]

60. Li, X.-L.; Wu, K.-N.; Chu, X.-X.; Yang, Q.-J.; Zhang, X.-D.; Hao, S.-H. Research Progress and Prospects for Cultivated Land Productivity Evalutaion. China Land Science 2019, 33, 91-100. (In Chinese)

61. Ramankutty, N.; Mehrabi, Z.; Waha, K.; Jarvis, L.; Kremen, C.; Herrero, M.; Rieseberg, L.H. Trends in Global Agricultural Land Use: Implications for Environmental Health and Food Security. Annu. Rev. Plant. Biol. 2018, 69, 789-815. [CrossRef]

62. Zhang, W.-K. Sustainable development of cultivated land: The case of north region of Meizhou Bay. Resour. Sci. 2002, 1, 20-24. (In Chinese) [CrossRef]

63. Wen, L.-Y.; Kong, X.-B.; Zhang, B.-B.; Sun, X.-B.; Xin, Y.-N.; Zhang, Q.-P. Construction and application of arable land quality evaluation system based on sustainable development demand. Trans. Chin. Soc. Agric. Eng. 2019, 35, 234-242. (In Chinese) [CrossRef]

64. Liu, H.-B.; Wang, Q.-B.; Wu, Y.; Wang, D.-P.; Yan, Y.-W. Research on Cognition Degree, Behavioral Decision Response of Rural Households and Impact Mechanism in cultivated land quality Protection. China Land Sci. 2018, 32, 52-58. (In Chinese)

65. Zhao, Q.-G. Emphasis on immigration and environmental construction in the Three Gorges reservoir area. Soil 1993, 2, 57-59. (In Chinese) [CrossRef]

66. Si, Z.-Z.; Li, M.; Qiu, W.-L.; Yun, W.-J. Regional Difference Analysis and Preservation of Cultivated Land Resources in China. J. Nat. Resour. 2010, 25, 713-721. (In Chinese) [CrossRef]

67. Bünemann, E.K.; Bongiorno, G.; Bai, Z.; Creamer, R.E.; De Deyn, G.; de Goede, R.; Fleskens, L.; Geissen, V.; Kuyper, T.W.; Mäder, P.; et al. Soil quality-A critical review. Soil Biol. Biochem. 2018, 120, 105-125. [CrossRef]

68. Rinot, O.; Levy, G.J.; Steinberger, Y.; Svoray, T.; Eshel, G. Soil health assessment: A critical review of current methodologies and a proposed new approach. Sci. Total Environ. 2019, 15, 1484-1491. [CrossRef] [PubMed]

69. Mueller, L.; Schindler, U.; Shepherd, T.G.; Ball, B.C.; Smolentseva, E.; Hu, C.; Hennings, V.; Schad, P.; Rogasik, J.; Zeitz, J.; et al. A framework for assessing agricultural soil quality on a global scale. Arch Agron Soil Sci. 2012, 58 (Suppl. 1), S76-S82. [CrossRef]

70. Zhao, R.; Wu, K.-N.; Zhang, X.-D.; Feng, Z. Evaluation on Farmland Health Productivity in Main Grain Production Areas: A Case Study in Wen County of Henan Province. China Land Sci. 2019, 33, 67-75. (In Chinese)

71. Yuan, Y.; Shi, X.; Zhao, Z. Land Use Types and Geomorphic Settings Reflected in Soil Organic Carbon Distribution at the Scale of Watershed. Sustainability 2018, 10, 3490. [CrossRef]

72. Abdelaal, H.S.A.; Thilmany, D. Grains Production Prospects and Long Run Food Security in Egypt. Sustainability 2019, 11, 4457. [CrossRef]

73. Nannipieri, P.; Ascher-Jenull, J.; Ceccherini, M.T.; Landi, L.; Pietramellara, G.; Renella, G. Microbial diversity and soil functions Eur. J. Soil Sci. 2003, 54, 655-670. [CrossRef]

74. Luo, X.; Feng, S.; Liu, H.; Zhao, B. Large-Scale Grain Producers' Application of Land Conservation Technologies in China: Correlation Effects and Determinants. Sustainability 2019, 11, 441. [CrossRef]

75. Dumanski, J.; Pieri, C. Land quality indicators: Research plan. Agric. Ecosyst. Environ. 2000, 81, 93-102. [CrossRef]

76. Wienhold, B.J.; Karlen, D.L.; Andrews, S.S.; Stott, D.E. Protocol for indicator scoring in the soil management assessment framework (SMAF). Renew. Agric. Food Syst. 2009, 24, 260-266. [CrossRef]

77. Mulder, V.L.; van Eck, C.M.; Friedlingstein, P.; Arrouays, D.; Regnier, P. Controlling factors for land productivity under extreme climatic events in continental Europe and the Mediterranean Basin. Catena 2019, 182, 104124. [CrossRef]

78. Ma, J.; Zhang, C.; Yun, W.; Lv, Y.; Chen, W.; Zhu, D. The Temporal Analysis of Regional Cultivated Land Productivity with GPP Based on 2000-2018 MODIS Data. Sustainability 2020, 12, 411. [CrossRef]

79. Chen, Y.-M.; Yao, M.-R.; Zhao, Q.-Q.; Chen, Z.-J.; Jiang, P.-H.; Li, M.-C.; Chen, D. Delineation of a basic farmland protection zone based on spatial connectivity and comprehensive quality evaluation: A case study of Changsha City, China. Land Use Policy 2020, 101, 105145. [CrossRef]

80. Yin, S.; Li, J.; Liang, J.; Jia, K.; Yang, Z.; Wang, Y. Optimization of the Weighted Linear Combination Method for Agricultural Land Suitability Evaluation Considering Current Land Use and Regional Differences. Sustainability 2020, 12, 10134. [CrossRef]

81. Yang, Y.-J.; Song, G.; Lu, S. Assessment of land ecosystem health with Monte Carlo simulation: A case study in Qiqihaer, China. J. Clean Prod. 2020, 250, 119522. [CrossRef]

82. Jiang, G.-H.; Wang, M.-Z.; Qu, Y.-B.; Zhou, D.-Y.; Ma, W.-Q. Towards cultivated land multifunction assessment in China: Applying the "influencing factors-functions-products-demands" integrated framework. Land Use Policy 2020, 99, 104982. [CrossRef]

83. Tyler, M.; Hunter, L.; Steiner, F.; Roe, D. Use of agricultural land assessment and site assessment in Whitman County, Washington, USA. Environ. Manag. 1987, 11, 407-412. [CrossRef]

84. Li, L. Towards a protocol on fair compensation in cases of legitimate land tenure changes: Input document for a participatory process. J. Chin. Gov. 2018, 1, 124-127. [CrossRef]

85. Feng, Y.; Yang, Q.; Tong, X.; Chen, L. Evaluating land ecological security and examining its relationships with driving factors using GIS and generalized additive model. Sci. Total Environ. 2018, 633, 1469-1479. [CrossRef]

86. Norris, C.E.; Bean, G.M.; Cappellazzi, S.B.; Cope, M.; Greub, K.L.H.; Liptzin, D.; Rieke, E.L.; Tracy, P.W.; Morgan, C.L.S.; Honeycutt, C.W. Introducing the North American project to evaluate soil health measurements. Agron. J. 2020, 112, $3195-3215$. [CrossRef]

87. Nunes, M.R.; Karlen, D.L.; Veum, K.S.; Moorman, T.B.; Cambardella, C.A. Biological soil health indicators respond to tillage intensity: A US meta-analysis. Geoderma 2020, 369, 114335. [CrossRef] 